\title{
Proteomic Analysis of Retinal Tissue in an S100B Autoimmune Glaucoma Model
}

\author{
Sabrina Reinehr ${ }^{1,+} \oplus$, Annika Guntermann ${ }^{2,+}$, Janine Theile ${ }^{1}$, Lara Benning ${ }^{1}$, Pia Grotegut ${ }^{1}$, \\ Sandra Kuehn ${ }^{1}$, Bettina Serschnitzki ${ }^{2}$, H. Burkhard Dick ${ }^{1} \mathbb{D}$, Katrin Marcus ${ }^{2} \mathbb{D}$, Stephanie C. Joachim ${ }^{1, *,+} \mathbb{D}^{\mathbb{D}}$ \\ and Caroline May $2, *,+\mathbb{D}$ \\ 1 Experimental Eye Research Institute, University Eye Hospital, Ruhr-University Bochum, \\ In der Schornau 23-25, 44892 Bochum, Germany; sabrina.reinehr@rub.de (S.R.); janine.theile@rub.de (J.T.); \\ Lara.Benning@uni-wh.de (L.B.); pia.grotegut@rub.de (P.G.); sandra.kuehn@rub.de (S.K.); \\ Burkhard.dick@kk-bochum.de (H.B.D.) \\ 2 Department Functional Proteomics, Medizinisches Proteom-Center, Ruhr-University Bochum, \\ ProDi E2.227, Gesundheitscampus 4, 44780 Bochum, Germany; annika.guntermann@rub.de (A.G.); \\ bettina.serschnitzki@rub.de (B.S.); katrin.marcus@rub.de (K.M.) \\ * Correspondence: stephanie.joachim@rub.de (S.C.J.); caroline.may@rub.de (C.M.); \\ Tel.: +49-234-2993156 (S.C.J.); +49-234-3218105 (C.M.) \\ + These authors contributed equally to this work.
}

Citation: Reinehr, S.; Guntermann, A.; Theile, J.; Benning, L.; Grotegut, P.; Kuehn, S.; Serschnitzki, B.; Dick, H.B.; Marcus, K.; Joachim, S.C.; et al.

Proteomic Analysis of Retinal Tissue in an S100B Autoimmune Glaucoma Model. Biology 2022, 11, 16. https:// doi.org/10.3390/biology11010016

Academic Editor: Deborah Penque

Received: 19 October 2021

Accepted: 20 December 2021

Published: 23 December 2021

Publisher's Note: MDPI stays neutral with regard to jurisdictional claims in published maps and institutional affiliations.

Copyright: (C) 2021 by the authors. Licensee MDPI, Basel, Switzerland. This article is an open access article distributed under the terms and conditions of the Creative Commons Attribution (CC BY) license (https:// creativecommons.org/licenses/by/ $4.0 /)$.
Simple Summary: Preventing blindness is an urgent need in a permanently further aging society. Glaucoma is one of the most common causes for blindness, but the exact pathomechanisms are not yet fully understood. Although an elevated intraocular pressure is a major risk factor, patients can have symptoms under normal pressure. Studies point towards an involvement of the immune system in glaucoma. Hence, in an animal model, where immunization with ocular antigens leads to intraocular-independent glaucomatous damage, we took a closer look into the pathophysiology with the help of proteomics. The proteomic analyses revealed significant alterations of proteins already at 7 and 14 days after immunization, before glaucomatous degeneration occurs. These proteins are often associated with the immune system. Hence, these data underline the important role of immunological factors in glaucoma. In the future, these factors might serve as disease markers.

Abstract: Glaucoma is a neurodegenerative disease that leads to damage of retinal ganglion cells and the optic nerve. Patients display altered antibody profiles and increased antibody titer, e.g., against S100B. To identify the meaning of these antibodies, animals were immunized with S100B. Retinal ganglion cell loss, optic nerve degeneration, and increased glial cell activity were noted. Here, we aimed to gain more insights into the pathophysiology from a proteomic point of view. Hence, rats were immunized with S100B, while controls received sodium chloride. After 7 and 14 days, retinae were analyzed through mass spectrometry and immunohistology. Using data-independent acquisition-based mass spectrometry, we identified more than 1700 proteins on a high confidence level for both study groups, respectively. Of these 1700, 43 proteins were significantly altered in retinae after 7 days and 67 proteins revealed significant alterations at 14 days. For example, $\alpha 2$ macroglobulin was found significantly increased not only by mass spectrometry analysis, but also with immunohistological staining in S100B retinae at 7 and 14 days. All in all, the identified proteins are often associated with the immune system, such as heat shock protein 60 . Once more, these data underline the important role of immunological factors in glaucoma pathogenesis.

Keywords: autoimmune; normal-tension; proteomics; S100B; HSP60; $\alpha 2$-macroglobulin; DIA mass spectrometric analysis; glaucoma; mass spectrometry

\section{Introduction}

Glaucoma, one of the most common causes for blindness worldwide, comprises a variety of eye diseases, whose pathological hallmark is a progressive loss of retinal ganglion 
cells (RGC) and their corresponding axons [1]. In the initial disease stages, the core clinical feature is visual field loss, which often remains unnoticed by the patient. When patients are firstly clinical diagnosed, the neuropathy is unfortunately often far progressed due to a long asymptomatic clinical phase. Hence, about $10-50 \%$ of patients are unaware that they are affected by this disease [2-6]. The precise etiology in most people suffering from glaucoma is still unknown. High intraocular pressure (IOP) has been identified as the main risk factor, and it is known that blocking the axonal protein transport at the lamina cribrosa causes an initial axonal damage and RGC death by trophic insufficiency. However, normal-tension glaucoma (NTG) occurs in patients with physiological IOP [7] and accounts for about $30 \%$ of glaucoma cases [8].

In addition to elevated IOP, ischemic/hypoxic damage [9], astrocyte and glia cell alterations, as well as excessive stimulation of the glutamatergic system [10] are discussed as possible pathomechanisms. An involvement of the immune system is also considered [11-13], due to the observation of up- and down-regulations in the systemic as well as the ocular antibody profiles in glaucoma patients [14-16]. Additionally, antibody deposits were demonstrated in glaucomatous retinae [17]. It is likely that a combination of several pathogenic factors and mechanisms increases the possibility of developing glaucoma.

Currently, glaucoma treatment is based on sustained IOP lowering, which can slow down, but not halt, disease progression [18,19]. In addition, the side effects of the topical drug medication are not insignificant and can lead to ocular irritation, decreasing the compliance of patients [20]. The social, economic, and emotional burden that the blindness, resulting from the disease, poses on patients and their relatives should not be neglected. These facts emphasize the importance of discovering new pharmacological strategies to prevent patients from going blind and, with that, losing their autotomy.

For the investigation of pathomechanisms and novel therapies, it is necessary to have suitable models that allow for such screening. To inquire whether antibodies detected in glaucoma patients are part of glaucoma pathogenesis or a result of disease progression, the experimental autoimmune glaucoma (EAG) animal model was established. This animal model is based on findings in glaucoma patients. A high autoantibody titer against S100B, a small calcium binding protein, was detected in samples from glaucoma patients [21]. In the central nervous system, S100B is mainly expressed by glial cells, such as oligodendrocytes, Schwann cells, ependymal cells, retinal Müller cells, and astrocytes [22]. S100B regulates and maintains the homeostasis of the important second messenger calcium and is, therefore, involved in many cell activities, such as signal transduction, cell differentiation, the regulation of cell motility, transcription, and cell cycle processes [23,24]. Extracellularly, $\mathrm{S} 100 \mathrm{~B}$ can act as a signal molecule and bind to receptors, such as the receptor for advanced glycation end products (RAGE). In high concentrations, S100B can have negative effects and lead to cell death. For example, the binding of RAGE can induce the activation of microglia cells, leading to a release of proinflammatory cytokines to an excessive extent [25]. Furthermore, there seems to be a link between S100B and different neuronal diseases [26].

In a previous study, we could observe that immunization with S100B in rats led to a significant loss of RGCs after 28 days and a fast degeneration of optic nerves. Interestingly, the IOP in this model was not altered [27]. Therefore, S100B immunization can be used to mimic the effects seen in NTG. The purpose of the presented study was to discover pathological pathways underlying glaucoma using the EAG model. Therefore, retinae were prepared and lysed; then, altered proteins were, for the first time, analyzed with mass spectrometry in data-independent acquisition (DIA) mode 7 and 14 days after S100B immunization. DIA leads, in contrast to data-dependent acquisition, to a more complete map of the fragment ion spectra, because all ions in a predefined mass/charge $(\mathrm{m} / \mathrm{z})$ range (or, time window) are fragmented. Based on this, DIA is gaining increasing importance for comprehensive label-free mass spectrometric analysis. Additionally, we performed immunohistological evaluations of different proteins, which were found to be altered in the mass spectrometry study. 


\section{Materials and Methods}

\subsection{Animals}

All procedures concerning animals adhered to the ARVO statement for the use of animals in ophthalmic and vision research. All experiments involving animals were approved by the animal care committee of North Rhine-Westphalia, Germany, and were performed in accordance with relevant guidelines and regulations (approval codes: 84-02.04.2013_A291 and 81-02.04.2019_A071).

Male Lewis rats (Charles River, Wilmington, MA, USA), 6 weeks of age, were used for the experiments and kept under environmentally controlled conditions with free access to chow and water ( $n=9 /$ group/point in time). Detailed observations and health checks, including eye exams, were performed regularly, as described previously [28].

\subsection{Immunization}

Rats received a single dose of $1 \mathrm{mg} / \mathrm{mL}$ S100B (Sigma-Aldrich, St. Louis, MO, USA) intraperitoneally [29]. The antigen was first mixed with incomplete Freund's adjuvant $(200 \mu \mathrm{L})$ plus $3 \mu \mathrm{g}$ pertussis toxin (both Sigma-Aldrich). The animals of the control group were injected with $0.9 \%$ sodium chloride with equivalent doses of Freund's adjuvant and pertussis toxin.

To obtain the retinae for proteomic analysis and (immune-)histology, animals were sacrificed 7 and 14 days after immunization by carbon dioxide inhalation.

\subsection{Mass Spectrometric Analysis of Retinae Samples}

The preparation of 6 pooled retinae samples for the creation of a retina-specific spectral library was described previously by Reinehr et al. [30]. Briefly, the eyes were enucleated, retinae were carefully extracted, and homogenization was performed by sonication.

The preparation of the actual study samples ( $n=8 /$ group/point in time) for DIA-based measurements was performed with minor changes. In total, $20 \mu \mathrm{g}$ of each retina lysate was loaded on a NuPAGE ${ }^{\mathrm{TM}}$ 10\% Bis-Tris gel (Fisher Scientific Inc., Waltham, MA, USA). Gel electrophoresis was limited to $50 \mathrm{~V}$ for $15 \mathrm{~min}$. After stopping electrophoresis, gels were stained with Coomassie blue (SimpleBlue ${ }^{\mathrm{TM}}$ SafeStain, Fisher Scientific Inc.) according to the manufacturer's instructions. The resulting single protein band per lane was dissected and transferred into a new glass vial. The protein bands were destained, $\mathrm{pH}$ was adjusted, and disulphide bridges were reduced as well as modified. After finishing the incubation cycle, gel pieces were dried and resuspended in $9.5 \mu \mathrm{L}$ trypsin solution $(0.033 \mu \mathrm{g} / \mu \mathrm{L}$; SERVA Electrophoresis GmbH, Heidelberg, Germany) plus $12 \mu \mathrm{L} 50 \mathrm{mM}$ ammonium bicarbonate. Trypsin digestion and the elution of peptides were performed as described earlier [30]. The resulting peptide extract was completely dried in a vacuum concentrator and resuspended in $30 \mu \mathrm{L} 0.1 \%(v / v)$ trifluoroacetic acid. The peptide concentration was determined with amino acid analysis [31]. For mass spectrometric analysis, $80 \mathrm{ng}$ of this peptide extract were transferred to a new glass vial and filed up to a volume of $14.5 \mu \mathrm{L}$ with $0.1 \%(v / v)$ trifluoroacetic acid. Finally, $1 \mu \mathrm{L}$ "indexed Retention Time" (iRT) peptides (Biognosys AG; Schlieren, Switzerland) were added to each retina sample.

The mass spectrometric analysis for the study samples was comparable to the spectral library samples performed with a Q Exactive ${ }^{\mathrm{TM}} \mathrm{HF}$ mass spectrometer (Fisher Scientific Inc.) but in DIA mode. The scan range for the full MS1 was set to 350 to $1100 \mathrm{~m} / \mathrm{z}$ with a resolution of 120,000. Fragmentation was performed by HCD with a resolution of 30,000 and a stepwise NCE of $25.5 \%, 27 \%$, and 30\%. The first fixed mass was set to $200 \mathrm{~m} / \mathrm{z}$ (ACG 3e6, maximum injection time automatic) and the default charge state set to $\geq+4$. The thereby generated date set for the study samples has been uploaded to ProteomeXchange with the identifier PXD023995.

\subsection{Data Evaluation and Functional Analysis}

Acquired mass spectrometric data were analyzed with the interface Spectronaut ${ }^{\mathrm{TM}}$ Pulsar (Biognosys) with default settings and minor changes, as used in Barkovits et al. [32]. 
Briefly summarized, the retina sample dataset described previously [30] was taken to generate a retina-specific spectral library (reference data set). The false discovery rate (called Qvalue) was set to a threshold of 1\%. For further statistical evaluation, proteins had to be quantified in at least $80 \%$ of the samples of one study group. Further filter criteria, such as a ratio $>30 \%$ (fold change of more than 1.3) and a Student's $t$-test with $p<0.05$, were calculated manually $\left.{ }^{*} p<0.05,{ }^{* *} p<0.01,{ }^{* * *} p<0.001\right)$.

For a functional proteomic analysis, the Reactome pathway database was used, a curated database for the visualization, interpretation, and analysis of pathway knowledge [33]. Importantly, all protein IDs were mapped to human equivalents prior to analysis. A binomial test was used to calculate the probability shown for each result and the $p$-values were corrected for the multiple testing (Benjamini-Hochberg procedure) that arises from evaluating the submitted list of identifiers against every pathway. Additionally, all proteins were further evaluated with the STRING bioinformatic database, which provides a comprehensive overview of the direct and indirect relationships as well as the interactions between proteins [34].

\subsection{Tissue Preparation for Immunohistology}

At 7 and 14 days after immunization, the control and the S100B eyes were enucleated and fixed in $4 \%$ paraformaldehyde for $60 \mathrm{~min}$. Subsequently, the rat eyes were treated with $30 \%$ sucrose and were embedded in a Neg-50 compound (Tissue Tek; Fisher Scientific Inc.). On a cryostat (Fisher Scientific Inc.), 10- $\mu \mathrm{m}$ cross-sections were cut, mounted on microtome slides (Histobond, Paul Marienfeld GmbH \& Co. KG, Lauda-Königshofen, Germany), and dried overnight. Afterwards, the sections were fixed in ice-cold acetone (VWR, Radnor, DE, USA) for $10 \mathrm{~min}$.

\subsection{Hematoxylin and Eosin Staining}

Exemplary retinal cross-sections from both groups and points in time were stained with hematoxylin and eosin (H\&E; both Merck, Darmstadt, Germany), dehydrated in ethanol, and treated with xylene before the sections were covered with Eukitt (O.Kindler, Bobingen, Germany). Images were acquired at $200 \times$ magnification using an Axio Imager M1 microscope (Zeiss, Oberkochen, Germany).

\subsection{Immunofluorescence Staining}

The immunofluorescence staining of specific cell types in the retina was performed as described previously ( $n=5$ /group/point in time) [27]. First, all cross-sections (6 sections/eye) were blocked with a mixture of 10-20\% serum, 0.1\% TritonX-100 (Sigma-Aldrich), and PBS (Biochrome, Schaffhausen, Germany) for one hour. The specific first antibodies (Table S1) were diluted in the same mixture and incubated overnight at room temperature. After three washing steps with PBS, all sections were incubated with Alexa Fluor 555- or Alexa Fluor 488-labelled secondary antibodies (Table S1). To visualize cell nuclei, 4',6 diamidino-2phenylindole (DAPI; SERVA Electrophoresis $\mathrm{GmbH}$ ), diluted in distilled water, was applied to the sections. Finally, the sections were covered with Shandon-Mount (Fisher Scientific Inc.). Negative controls were performed for all antibody stains using only secondary antibodies.

\subsection{Histological Evaluation}

Four images (two peripheral and two central) per retinal cross-section were acquired at $400 \times$ magnification using the Axio Imager M2 microscope (Zeiss). Afterwards, an equal area of each picture was cut out using Corel Paint Shop software (Corel Corporation, Ottawa, ON, Canada).

The number of RNA-binding proteins with multiple splicing (RBPMS) ${ }^{+}$cells in the ganglion cell layer and calretinin ${ }^{+}$cells in the inner nuclear layer were counted using ImageJ software (National Institute of Health, Bethesda, MD, USA). To measure the area of HSP60 and $\alpha 2$-macroglobulin, pictures were processed using an ImageJ macro (National Institute 
of Health), as described previously [35,36]. Briefly, pictures were converted into greyscale (32-bit), and a rolling ball radius of 40 pixels was subtracted to minimize background interference. Further, a proper lower threshold was determined for each picture, which was achieved when the greyscale picture corresponded to the original one. At the end, the mean value was calculated, and this number was used for the final analyses (HSP60: 15.49; $\alpha 2$-macroglobulin: 10.36). The upper threshold was set as the highest number out of all pictures (HSP60: 254.90; $\alpha 2$-macroglobulin: 246.01). Between these defined lower and upper thresholds, the percentage of the labeled area of the staining was measured.

\subsection{Statistics of Immunohistology Evaluations}

Immunohistology data were shown as mean \pm standard error of the mean (SEM) and were statistically analyzed using the Statistica software (V13.3; Dell, Round Rock, TX, USA). Values of the control groups were set to 100\%. The S100B group was compared to the controls by applying Student's $t$-test with $p<0.05$ considered statistically significant. ${ }^{*} p<0.05,{ }^{* *} p<0.01$, and ${ }^{* * *} p<0.001$.

\section{Results}

The study compromises two study groups, the S100B and the control group, with, in total, 18 rats per group for proteomic analysis. Respectively, nine rats from each study group were prepared 7 days after immunization and the remaining nine rats per group 14 days after, for proteomic analysis. One sample from each group has been excluded due to insufficient protein yield after tissue preparation. Additionally, five retinae/group/point-in time were prepared for (immuno-)histology (Figure 1).

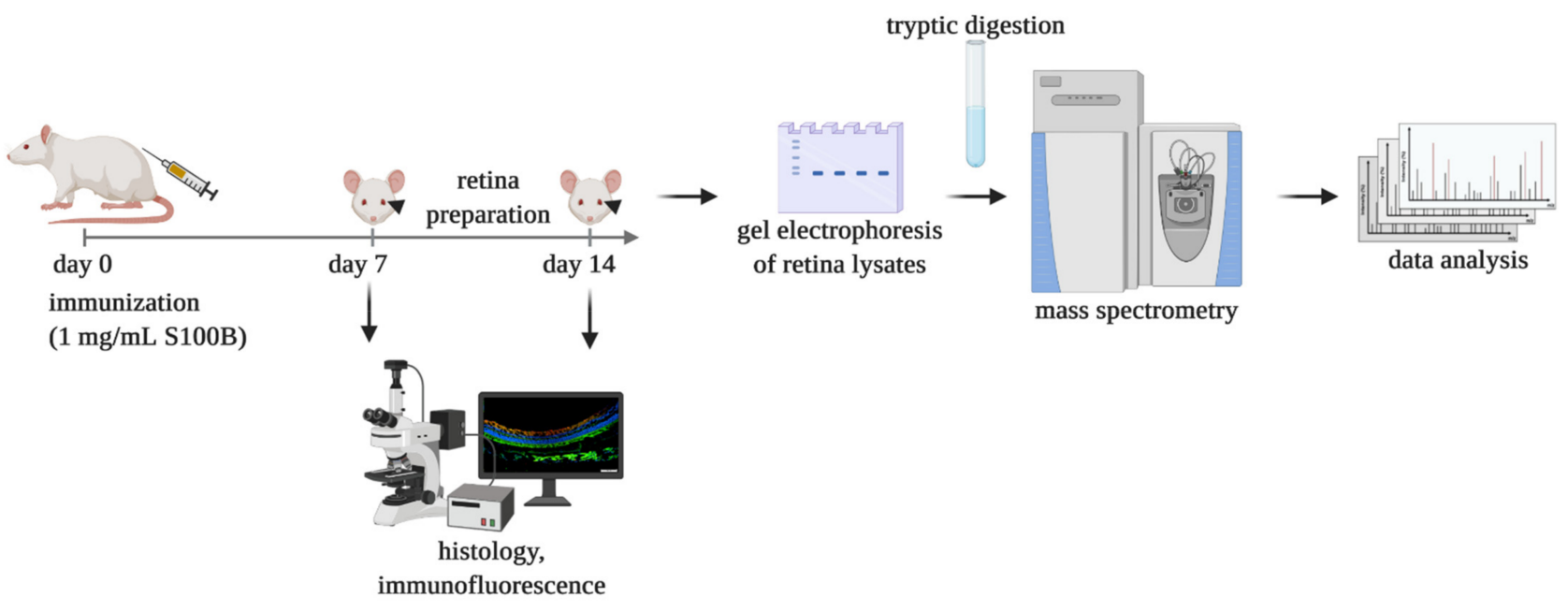

Figure 1. Study overview. Schematic study setup created with biorender.com (accessed on 15 October 2021).

\subsection{Characteristics of Proteins in the Retina-Specific Spectral Library}

For the characterization of differences within the proteome in consequence of immunization with S100B, a DIA-based mass spectrometry analysis was chosen. To this end, the before-generated retina-specific spectral library served as a consensus template [30]. It consists of mass spectrometric data of the ocular sinister of six rats acquired by data-dependent acquisition mass spectrometry. In this generated spectral library, 67,165 peptides, which were assigned to 4689 proteins, have been identified. For a more detailed characterization of these proteins, a pathway enrichment analysis was carried out using the Reactome pathway database [33]. As a result, one of at least 2725 mapped proteins covered 1988 biological pathways (Figure S1). 


\subsection{Comparative Proteomic Analysis Revealed Complex, Time-Dependent Regulations after S100B Immunization}

Based on the spectral library, the actual retinal proteomic data analysis in the framework of S100B immunization was carried out. The filtering steps during data evaluation are displayed in Figure 2. Within all 7-day study samples ( $n=8$ /group), 13,199 peptides, assigned to 1744 proteins, were identified. Proteins identified with at least one unique peptide in at least $80 \%$ of the control as well as the S100B samples were selected for further comparative proteome analysis. These 1287 proteins are reported in Table S2. Comparing the abundancies of the 7-day study groups, 43 proteins had a ratio of at least $>30 \%$, a $p$-value $<0.05$, and a FDR $<0.01$. Of these, 11 proteins were under-represented and 31 over-represented in the S100B study group 7 days after immunization (Figure 2).

\section{Contained in spectral library}

4689 proteins
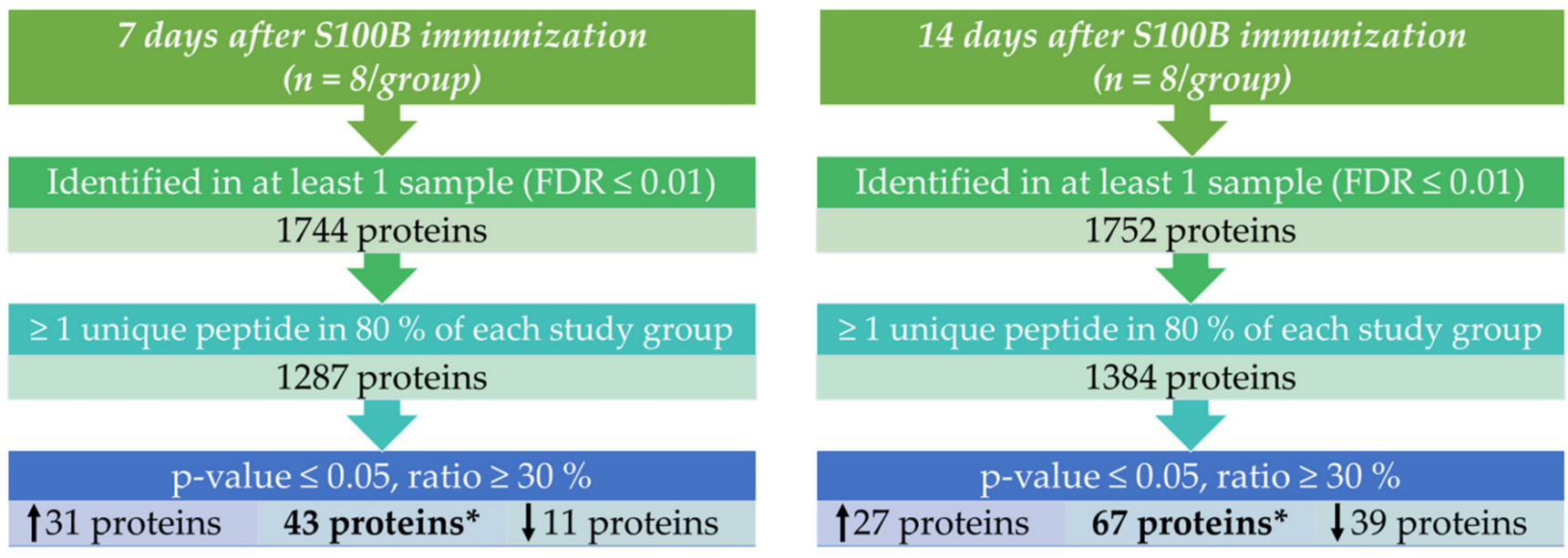

Figure 2. Flow chart of identified and filtered proteins for study groups at 7 as well as 14 days after S100B immunization ( $n=8$ /group). ${ }^{*}$ One protein showed both an up-regulated as well as a down-regulated peptide, compared to the control group.

Interestingly, stress-induced-phosphoprotein 1 revealed one peptide that was overrepresented, while another peptide assigned to this protein was under-represented in the S100B study group. The abundance of the 20 most differential proteins, when focusing on the smallest $p$-value 7 days after S100B immunization, is presented in Table 1.

The results of three exemplary differential proteins, known from the glaucoma literature, are visualized in Figure 3. Serotransferrin had four, myosin-10 had one, and microtubule-associated protein 2 (MAP-2) had two unique peptides, which were significantly expressed based on the filtering criteria.

The study group data for the 14-day time point were analogously evaluated and revealed 14,627 peptides that could be assigned to 1752 proteins. A total of 1384 proteins had at least one unique peptide and were identified in at least $80 \%$ of each study group (Table S3). Analysis of the abundancies of the 14-day time point study groups revealed 67 proteins with a ratio of at least $>30 \%$, a $p$-value $<0.05$, and a FDR $<0.01$. Overrepresented in the S100B study group were 27 proteins, under-represented were 39 proteins (Figure 2). Additionally, for this time point, cytoplasmic dynein 1 heavy chain 1 was a protein with an over-represented as well as an under-represented peptide in the S100B study group. The 20 most differential proteins 14 days after S100B injection with the smallest $p$-values are listed in Table 2. 
Table 1. The top 20 differential proteins 7 days after S100B immunization. Proteins quantified in $\geq 80 \%$ of the S100B and control groups are ranked based on the lowest $p$-value $(\leq 0.02)$.

\begin{tabular}{|c|c|c|c|c|c|}
\hline \multicolumn{6}{|c|}{7 Days after S100B Immunization } \\
\hline Statistical Rank & Uniprot ID & Protein Name & $\begin{array}{c}\text { Qvalue (FDR) } \\
\leq 0.01\end{array}$ & $\begin{array}{c}p \text {-Value } \\
\leq 0.02\end{array}$ & $\begin{array}{l}\text { Ratio } \\
\geq 30 \%\end{array}$ \\
\hline 1 & Q7TNY6 & Golgi resident protein GCP60 & $1.38 \times 10^{-3}$ & 0.002 & $48 \%$ \\
\hline 2 & O35814 & Stress-induced-phosphoprotein 1 & $1.15 \times 10^{-5}$ & 0.002 & $48 \%$ \\
\hline 3 & P25809 & Creatine kinase U-type, mitochondrial & $2.07 \times 10^{-7}$ & 0.004 & $35 \%$ \\
\hline 4 & P02770 & Albumin & $1.85 \times 10^{-10}$ & 0.005 & $33 \%$ \\
\hline 5 & P56574 & Isocitrate dehydrogenase [NADP], mitochondrial & $7.62 \times 10^{-4}$ & 0.006 & $53 \%$ \\
\hline 6 & P63004 & $\begin{array}{c}\text { Platelet-activating factor acetylhydrolase IB } \\
\text { subunit alpha }\end{array}$ & $3.21 \times 10^{-5}$ & 0.007 & $45 \%$ \\
\hline 7 & P12785 & Fatty acid synthase & $2.00 \times 10^{-6}$ & 0.007 & $57 \%$ \\
\hline 8 & P49432 & $\begin{array}{c}\text { Pyruvate dehydrogenase e } 1 \text { component subunit } \\
\text { beta, mitochondrial }\end{array}$ & $3.79 \times 10^{-6}$ & 0.010 & $108 \%$ \\
\hline 9 & P12346 & Serotransferrin & $2.08 \times 10^{-8}$ & 0.011 & $33 \%$ \\
\hline 10 & Q63151 & Long-chain-fatty-acid-CoA ligase 3 & $7.13 \times 10^{-4}$ & 0.012 & $45 \%$ \\
\hline 11 & P14841 & Cystatin-C & $3.09 \times 10^{-4}$ & 0.012 & $61 \%$ \\
\hline 12 & Q63598 & Plastin-3 & $1.39 \times 10^{-3}$ & 0.012 & $85 \%$ \\
\hline 13 & Q9JLT0 & Myosin-10 & $1.75 \times 10^{-4}$ & 0.013 & $43 \%$ \\
\hline 14 & Q924S5 & Lon protease homolog, mitochondrial & $4.22 \times 10^{-5}$ & 0.015 & $40 \%$ \\
\hline 15 & O70351 & 3-hydroxyacyl-CoA dehydrogenase type-2 & $9.91 \times 10^{-4}$ & 0.016 & $85 \%$ \\
\hline 16 & Q8K1P7 & Transcription activator BRG1 & $3.13 \times 10^{-9}$ & 0.018 & $55 \%$ \\
\hline 17 & P15146 & Microtubule-associated protein 2 & $3.03 \times 10^{-5}$ & 0.019 & $58 \%$ \\
\hline 18 & Q5PPM7 & Rod outer segment membrane protein 1 & $2.64 \times 10^{-9}$ & 0.021 & $51 \%$ \\
\hline 19 & P21531 & $60 S$ ribosomal protein L3 & $6.73 \times 10^{-5}$ & 0.021 & $31 \%$ \\
\hline 20 & Q5XI73 & Rho GDP-dissociation inhibitor 1 & $5.02 \times 10^{-7}$ & 0.021 & $77 \%$ \\
\hline
\end{tabular}

Table 2. The top 20 differential proteins 14 days after S100B immunization. Proteins that are quantified in $\geq 80 \%$ of the S100B and control groups are ranked based on the lowest $p$-value $(\leq 0.02)$.

\begin{tabular}{|c|c|c|c|c|c|}
\hline \multicolumn{6}{|c|}{14 Days after S100B Immunization } \\
\hline Statistical Rank & Uniprot ID & Protein Name & $\begin{array}{l}\text { Qvalue (FDR) } \\
\leq 0.01\end{array}$ & $\begin{array}{l}p \text {-Value } \\
\leq 0.02\end{array}$ & $\begin{array}{l}\text { Ratio } \\
\geq 30 \%\end{array}$ \\
\hline 1 & Q5XI31 & GPI transamidase component PIG-S & $3.05 \times 10^{-3}$ & 0.003 & $36 \%$ \\
\hline 2 & P11506 & Plasma membrane calcium-transporting ATPase 2 & $1.37 \times 10^{-8}$ & 0.003 & $54 \%$ \\
\hline 3 & P41542 & General vesicular transport factor p115 & $1.81 \times 10^{-4}$ & 0.003 & $46 \%$ \\
\hline 4 & P63039 & $60 \mathrm{kDa}$ heat shock protein, mitochondrial & $4.80 \times 10^{-11}$ & 0.004 & $45 \%$ \\
\hline 5 & P21670 & Proteasome subunit alpha type- 4 & $2.04 \times 10^{-7}$ & 0.005 & $69 \%$ \\
\hline 6 & Q9JK11 & Reticulon- 4 & $3.50 \times 10^{-9}$ & 0.010 & $37 \%$ \\
\hline 7 & Q62927 & cGMP-gated cation channel alpha-1 & $5.20 \times 10^{-6}$ & 0.011 & $30 \%$ \\
\hline 8 & Q9ePH8 & Polyadenylate-binding protein 1 & $1.99 \times 10^{-7}$ & 0.012 & $59 \%$ \\
\hline 9 & Q6IMY8 & Heterogeneous nuclear ribonucleoprotein $U$ & $4.57 \times 10^{-9}$ & 0.012 & $109 \%$ \\
\hline 10 & P14881 & Beta-crystallin A3 & $2.14 \times 10^{-10}$ & 0.013 & $298 \%$ \\
\hline 11 & D3ZLZ7 & Inosine-5'-monophosphate dehydrogenase 1 & $5.11 \times 10^{-10}$ & 0.015 & $32 \%$ \\
\hline 12 & O35476 & Medium-wave-sensitive opsin 1 & $1.18 \times 10^{-4}$ & 0.016 & $152 \%$ \\
\hline 13 & P63012 & Ras-related protein Rab-3A & $1.34 \times 10^{-8}$ & 0.016 & $41 \%$ \\
\hline 14 & P84083 & ADP-ribosylation factor 5 & $9.07 \times 10^{-8}$ & 0.017 & $37 \%$ \\
\hline 15 & P06761 & endoplasmic reticulum chaperone BiP & $8.01 \times 10^{-9}$ & 0.018 & $71 \%$ \\
\hline 16 & P02770 & Albumin & $3.75 \times 10^{-11}$ & 0.018 & $45 \%$ \\
\hline 17 & D3ZHV2 & Microtubule-actin cross-linking factor 1 & $2.31 \times 10^{-4}$ & 0.018 & $37 \%$ \\
\hline 18 & P62752 & $60 S$ ribosomal protein L23a & $4.00 \times 10^{-4}$ & 0.019 & $42 \%$ \\
\hline 19 & Q68FX0 & $\begin{array}{l}\text { Isocitrate dehydrogenase [NAD] subunit beta, } \\
\text { mitochondrial }\end{array}$ & $4.00 \times 10^{-7}$ & 0.020 & $32 \%$ \\
\hline 20 & P50475 & Alanine-tRNA ligase, cytoplasmic & $5.49 \times 10^{-8}$ & 0.020 & $78 \%$ \\
\hline
\end{tabular}




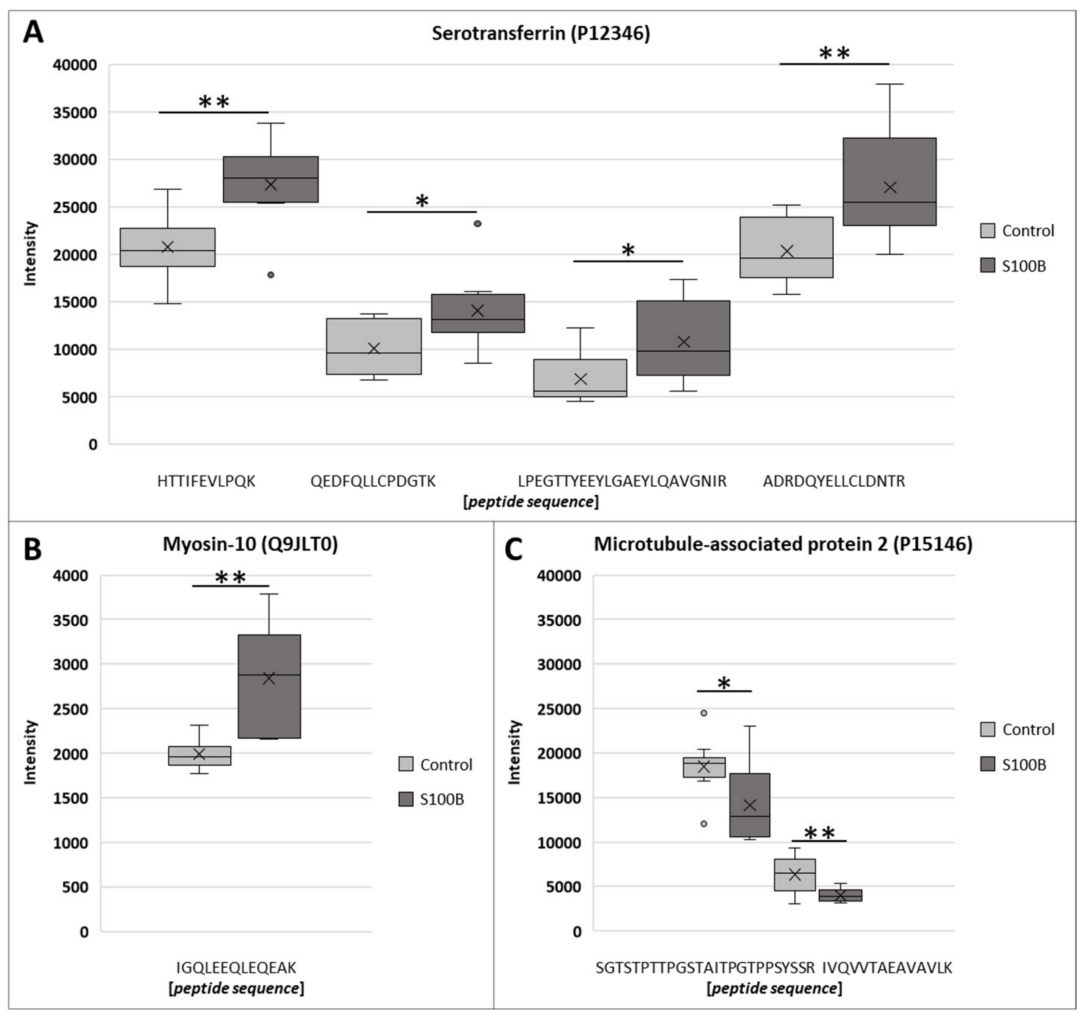

Figure 3. Mass spectrometry-based intensities of differential peptides with their assigned proteins 7 days after S100B injection. (A) Four unique peptides associated with serotransferrin and (B) one unique myosin-10 peptide were significantly up-regulated in rat retinae, 7 days after S100B immunization. (C) In contrast, two unique peptides of microtubule-associated protein 2 were significantly down-regulated in in rat retinae, 7 days after S100B immunization $\left({ }^{*} p<0.05,{ }^{* *} p \leq 0.01\right.$, ratio $\left.>30 \%\right)$.

In Figure 4, all identified peptides belonging to the protein gephyrin are shown. Recently, a significantly lower inhibitory post-synapse signal was visualized by anti-gephyrin in a later stage of retinal degeneration. Here, the intensity remained unchanged in comparison to the control group, confirming a recent study result - that 14 days after immunization might be too early in the retinal degeneration process of systemically immunized S100B animals [35].

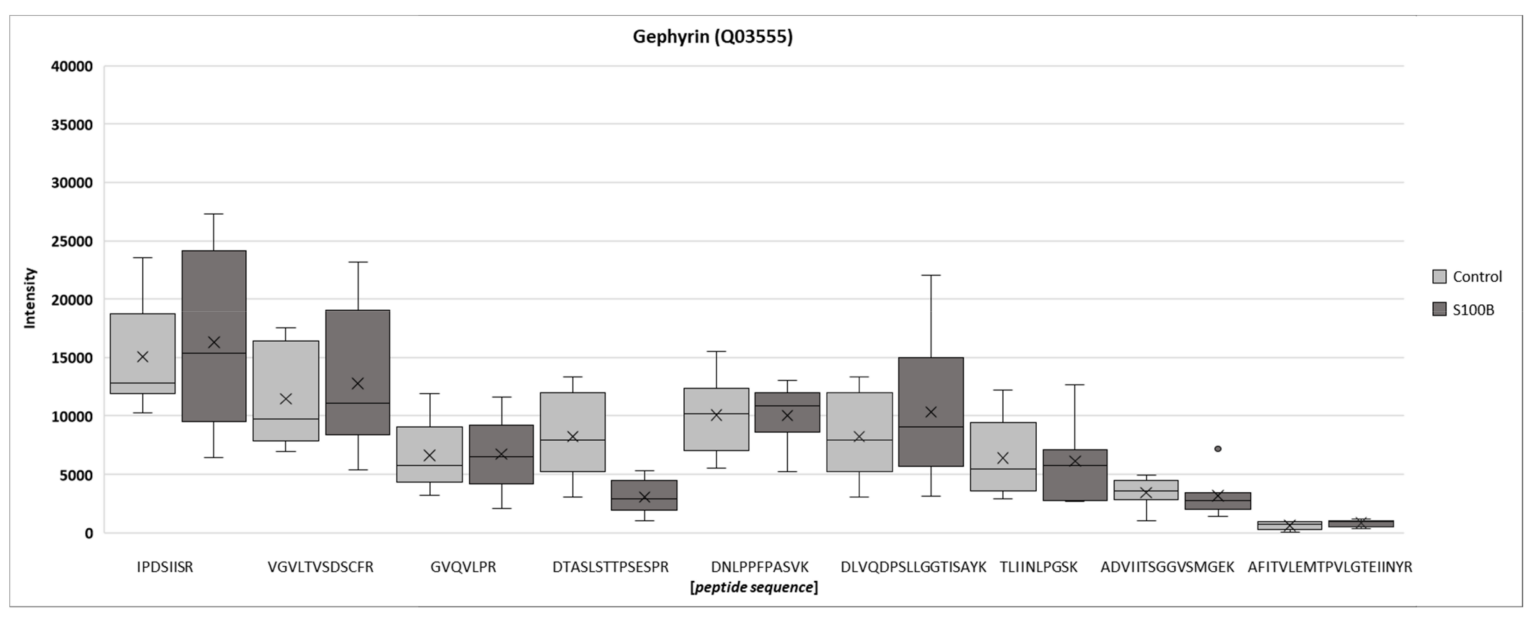

Figure 4. Mass spectrometry-based intensities of gephyrin 14 days after S100B injection. Nine unique peptides associated with gephyrin were differentially expressed in rat retinae 14 days after S100B immunization compared to control retinae (no significance). 
In total, 58 proteins were over-represented and 50 proteins under-represented, in the comparative analysis at both points in time after the S100B immunization.

\subsection{Characteristics of Differential Proteins}

For a more biological characterization of the identified proteins present in the rat retina after S100B immunization, they were analyzed with the Reactome pathway database. The results of the Reactome pathway analysis of the proteins contained in rat retinae after S100B immunization are visualized in Figure S2. For the retina samples of the 7-day immunization, 1225 proteins were mapped to 1641 biological pathways in total. Strong pathways were, e.g., found in the area metabolism of carbohydrates. In comparison, 1637 biological pathways were associated with at least one of the 1234 retinal proteins from S100B immunization after 14 days. Thereby, a similar pathway distribution compared to the other group was detectable. However, there seems to be a stronger over-representation of some proteins 14 days after S100B immunization.

In a next step, the STRING database provided a detailed protein-protein network of the 43 significant proteins (FDR $<0.01 ; p<0.05$; ratio $>30 \%$ ) 7 days after S100B immunization (Figure S3). There were mainly functional interactions related to the citric acid cycle, confirming even more that at least some individuals with glaucoma may have an impaired RGC energy metabolism [37]. In contrast, 14 days after S100B immunization, 67 significant proteins (FDR $<0.01 ; p<0.05$; ratio $>30 \%$ ) formed interaction networks that, among others, showed an involvement in glutamate processing (Figure S4). This indicates the controversial role of glutamate in retinal excitotoxicity and neuroprotection [38,39].

\subsection{No Loss of Retinal Ganglion Cells}

Exemplary retinal cross-sections were stained with H\&E at 7 and 14 days after immunization (Figure 5A). After S100B immunization, retinal layers appear normal in morphology, with no signs of inflammation or infiltration, compared to the controls at both points in time.
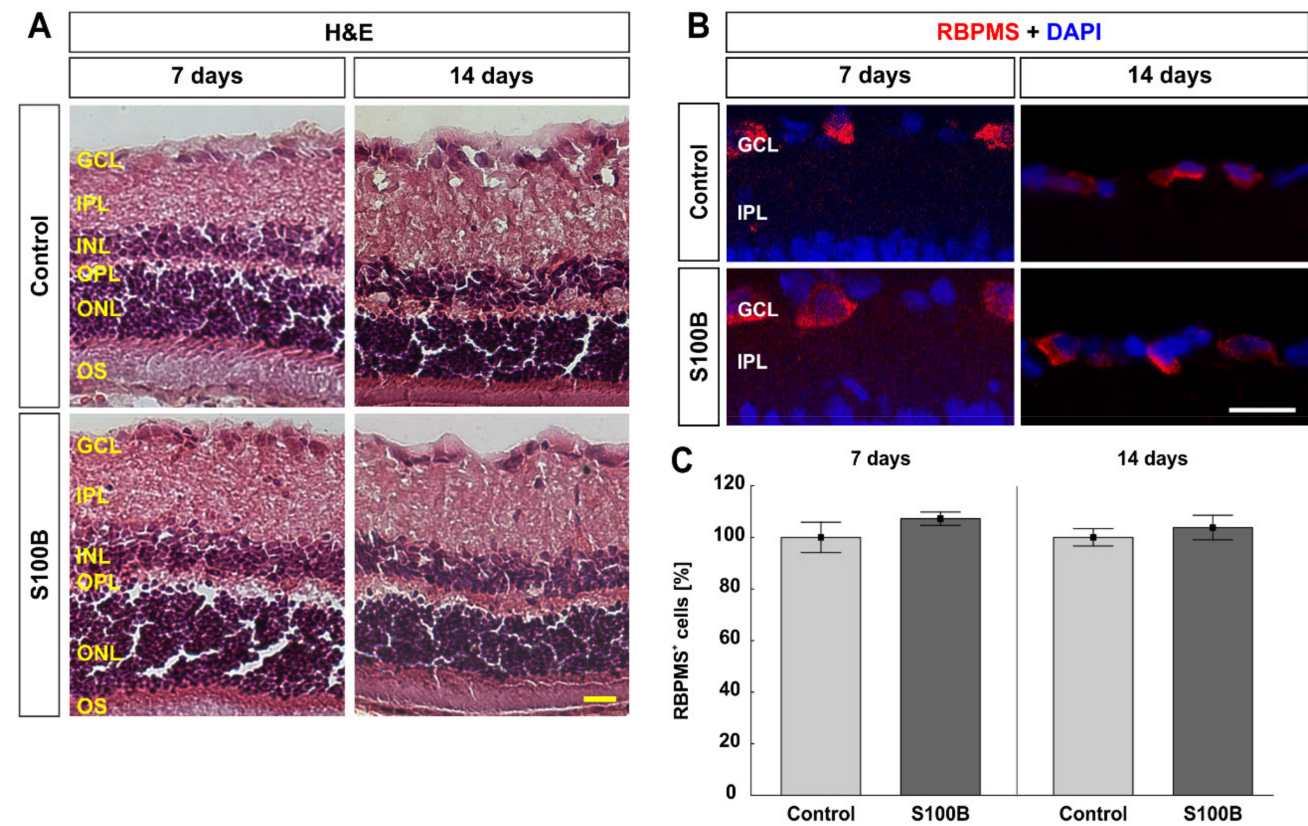

Figure 5. Intact retinal morphology and no retinal ganglion cell loss. (A) At 7 and 14 days after S100B immunization, the retinae showed no signs of inflammation or damage of the retinal layers. The morphology was comparable to those of the control group. (B) At 7 and 14 days after immunization, retinal cross-sections were labeled with an antibody against RBPMS (red; retinal ganglion cells). DAPI was used for counterstaining cell nuclei (blue). (C) The number of RBPMS ${ }^{+}$cells remained comparable 
between S100B and control animals at 7 and 14 days after immunization. Values are mean \pm SEM and control values were set to $100 \%$. GCL = ganglion cell layer; IPL = inner plexiform layer; $\mathrm{INL}=$ inner nuclear layer; $\mathrm{OPL}=$ outer plexiform layer; $\mathrm{ONL}=$ outer nuclear layer; $\mathrm{OS}=$ outer segment. Scale bars: $20 \mu \mathrm{m}$.

At 7 and 14 days after immunization, the number of RGCs was assessed by labeling retinal cross-sections with an antibody against RBPMS (Figure 5B). At 7 days, the number of RGCs was comparable in S100B (107.26 $\pm 2.57 \%)$ and control retinae $(100.00 \pm 5.89 \%$; $p=0.292$; Figure 5C). The number of RBPMS ${ }^{+}$RGCs was still not altered between the S100B (103.80 $\pm 4.77 \%)$ and control animals (100.00 $\pm 3.33 \% ; p=0.532$; Figure $5 \mathrm{C})$ after 14 days. A previous study revealed a RGC loss later on in this model, 28 days after S100B immunization [27].

\subsection{Altered Expression of Calretinin ${ }^{+}$Amacrine Cells}

Mass spectrometry-based intensities of calretinin (peptide sequence: GFLSDLLK) revealed a significant up-regulation in S100B retinae 14 days after immunization $(p=0.023$; Figure 6A). Then, possible changes in the number of amacrine cells were elaborated through an anti-calretinin staining 7 and 14 days after immunization (Figure 6B). At 7 days, the number of calretinin ${ }^{+}$cells was comparable in the S100B $(97.04 \pm 6.47 \%)$ and control retinae $(100.00 \pm 4.93 \% ; p=0.364$; Figure $6 \mathrm{C})$. Further, no alterations were noted in the number of calretinin $^{+}$amacrine cells in the $\mathrm{S} 100 \mathrm{~B}$ retinae $(102.06 \pm 4.20)$ compared to the controls $(100.00 \pm 5.98 \% ; p=0.785) 14$ days after immunization (Figure 6C).

A

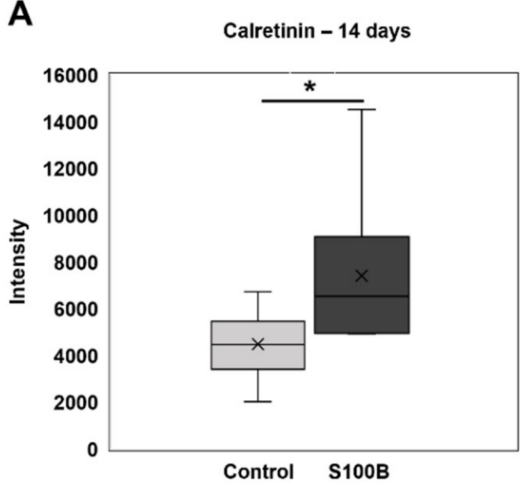

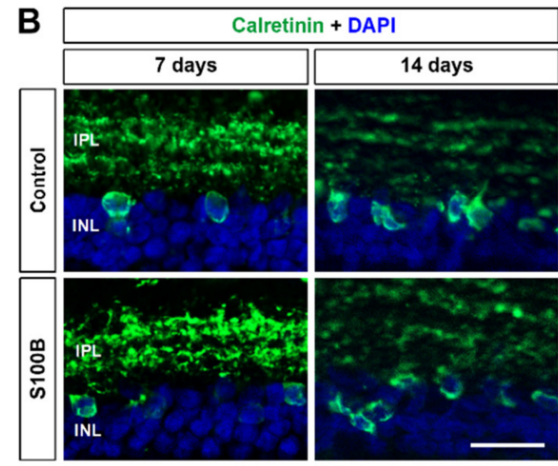

C

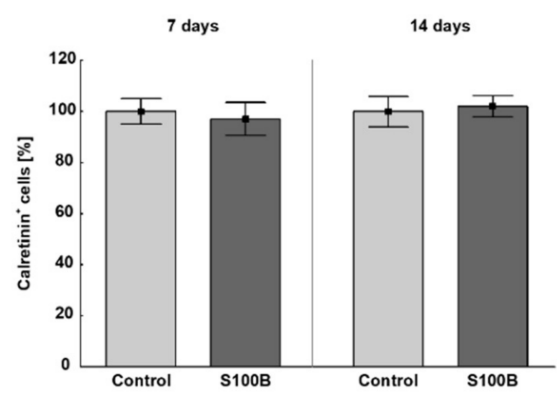

Figure 6. Altered calretinin expression. (A) Mass spectrometry analyses showed a significant upregulation of the calretinin intensity (peptide sequence: GFLSDLLK) 14 days after immunization $(p=0.023$ ). (B) Retinal cross-sections were stained with an anti-calretinin antibody (green) 7 and 14 days after immunization. DAPI was applied to visualize cell nuclei (blue). (C) The number of calretinin $^{+}$cells was not altered at either point in time. Values for immunohistology are mean \pm SEM and control values were set to $100 \%$. IPL = inner plexiform layer; INL = inner nuclear layer. Scale bar: $20 \mu \mathrm{m} .{ }^{*} p<0.05$.

\subsection{Different HSP60 Expression after Immunization}

Retina samples, which were analyzed using mass spectrometry, showed that the intensity of two peptide sequences of HSP60 (peptide sequences: KPLVIIAEDVDGEALSTLVLNR: $p=0.033$; DMAIATGGAVFGEEGLNLNLEDV-QAH-DLGK: $p=0.004$ ) were significantly down-regulated in S100B animals compared to controls (Figure 7A). The staining area of HSP60 was evaluated by immunohistology 7 and 14 days after immunization (Figure 7B). After 7 days, a significant increase of the $\mathrm{HSP}^{+} 0^{+}$staining area was revealed in S100B rats $(124.76 \pm 6.57 \%)$ compared to controls $(100.00 \pm 7.89 \% ; p=0.042$; Figure $7 \mathrm{C})$. The percentage of the $\mathrm{HSP}^{+}$area in S100B animals $(95.32 \pm 6.71 \%)$ went back to control level $(100.00 \pm 4.73 \% ; p=0.584)$ after 14 days (Figure $7 \mathrm{C})$. 
A

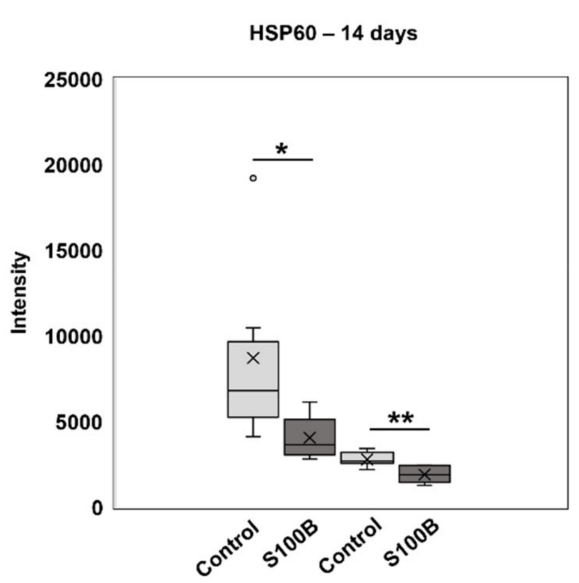

B

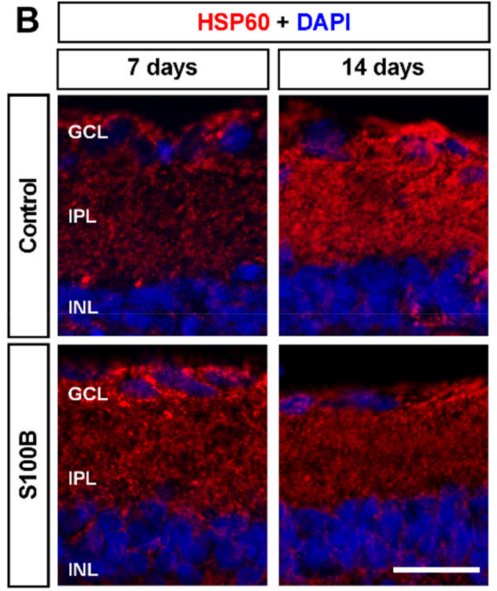

C

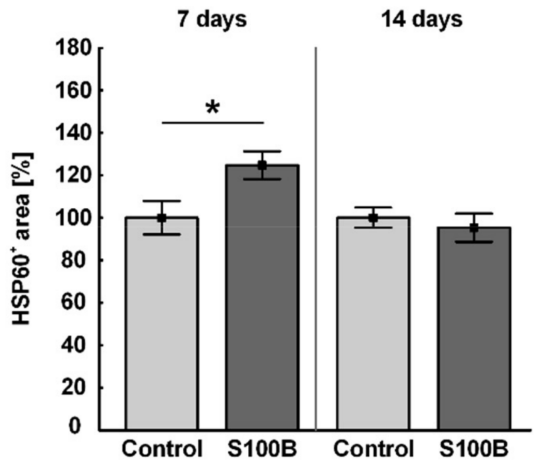

Figure 7. Altered HSP60 expression. (A) At 14 days after S100B immunization, the intensity of two peptide sequences of HSP60 was significantly down-regulated (peptide sequences: KPLVIIAEDVDGEALSTLVLNR: $p=0.033$; DMAIATGGAVFGEEGLNLNLEDVQAHDLGK: $p=0.004$ ). (B) An anti-HSP60 antibody (red) was applied on retinal cross-sections 7 and 14 days after immunization. DAPI was used to stain cell nuclei (blue). (C) At 7 days, the $\mathrm{HSP}^{+} 0^{+}$staining area was significantly increased in S100B animals $(p=0.042)$. No alterations were revealed between S100B and control retinae after 14 days. Values for immunohistology are mean \pm SEM and control values were set to $100 \% . \mathrm{GCL}=$ ganglion cell layer; $\mathrm{IPL}=$ inner plexiform layer; $\mathrm{INL}=$ inner nuclear layer. Scale bar: $20 \mu \mathrm{m} .{ }^{*} p<0.05 ;{ }^{* *} p<0.01$.

\subsection{Increased Levels of $\alpha 2-$ Macroglobulin in S100B Retinae}

Mass spectrometric analysis of $\alpha 2$-macroglobulin revealed an up-regulation of two different peptide sequences (peptide sequences: KPLVIIAEDVDGEALSTLVLNR and DMAIATGGAVFGEEGLNLNLEDVQAHDLGK) in S100B animals compared to controls 7 days after immunization (both: $p=0.006$; Figure $8 \mathrm{~A}$ ). At 7 and 14 days after immunization, retinal cross-sections were labelled against anti- $\alpha 2$-macroglobulin (Figure $8 \mathrm{~B}$ ). A significantly larger $\alpha 2$-macroglobulin ${ }^{+}$staining area could be noted in S100B retinae $(137.95 \pm 15.31 \%)$ compared to control ones $(100.00 \pm 4.19 \% ; p=0.044)$ after 7 days (Figure $8 \mathrm{C})$. Further, the $\alpha 2$ macroglobulin ${ }^{+}$staining area was significantly increased in S100B animals $(125.53 \pm 3.16 \%)$ when compared to control retinae $(100.00 \pm 8.21 \% ; p=0.020) 14$ days after immunization (Figure 8C).

A

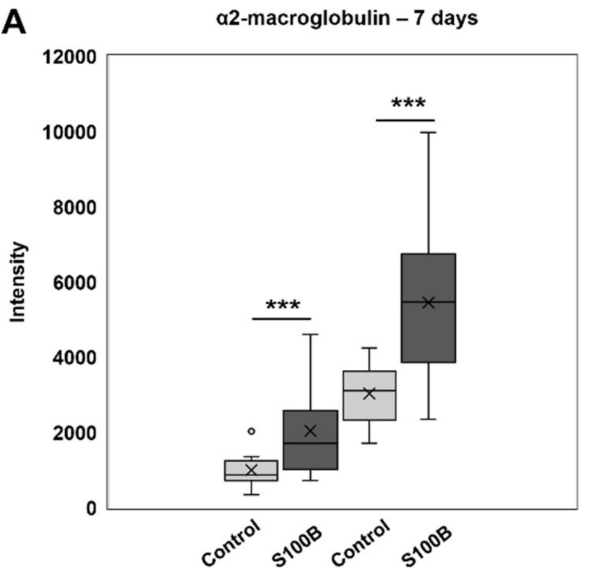

B

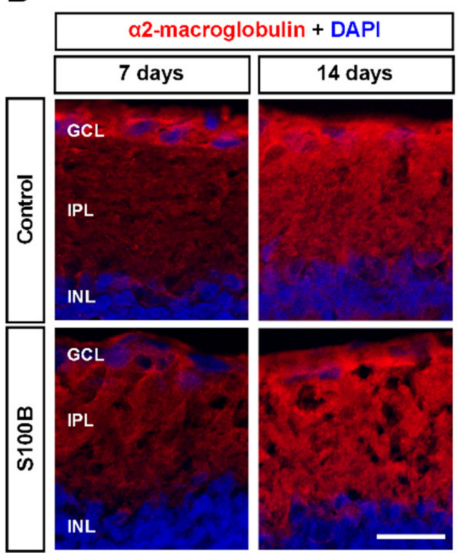

C

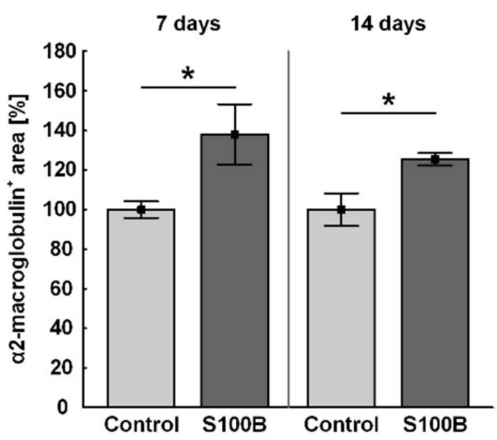

Figure 8. More $\alpha 2$-macroglobulin expression after immunization. (A) At 7 days after S100B immunization, the intensities of two peptide sequences of $\alpha 2$-macroglobulin were significantly up-regulated 
(both: $p=0.006$ ). (B) Retinal cross-sections were labelled with an antibody against $\alpha 2$-macroglobulin (red), while DAPI counterstained cell nuclei (blue). (C) The staining area of $\alpha 2$-macroglobulin was significantly increased $7(p=0.044)$ and 14 days after immunization $(p=0.020)$. Values for immunohistology are mean \pm SEM and control values were set to $100 \%$. GCL = ganglion cell layer; $\mathrm{IPL}=$ inner plexiform layer; INL = inner nuclear layer. Scale bar: $20 \mu \mathrm{m} .{ }^{*} p<0.05 ;{ }^{* * *} p<0.001$.

\subsection{Up-Regulation of Interphotoreceptor Matrix Proteoglycans and Plastin 3}

Further interesting proteins were found up-regulated by mass spectrometric analysis. The photoreceptor-specific extracellular matrix protein (ECM) interphotoreceptor matrix proteoglycan (IMPG) 1, for example, was significantly increased in S100B retinae 7 days after immunization ( $p=0.042$; Figure 9A). Immunohistological staining showed a distribution in control animals predominantly in the outer segment, while in S100B rats, IMPG1 ${ }^{+}$staining could also be revealed in the ganglion cell layer (GCL; Figure 9B).
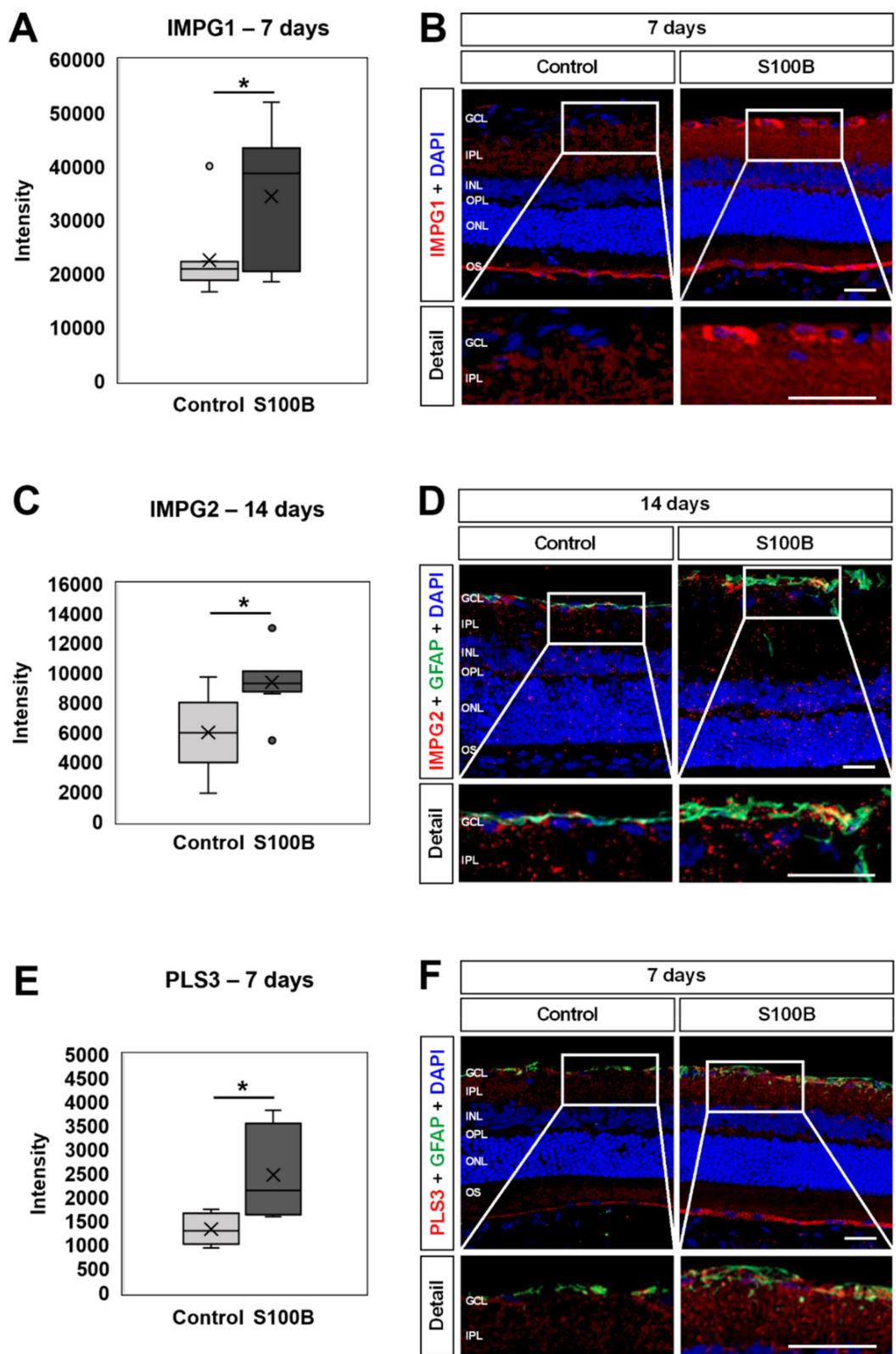

Figure 9. Up-regulated expression of various matrix proteins. (A) Mass spectrometry revealed an up-regulation of IMPG1 in S100B rats 7 days after immunization $(p=0.042)$. (B) Representative staining 
of anti-IMPG1 (red) on retinal cross-sections at 7 days. DAPI (blue) counterstained cell nuclei. IMPG1 staining was more distinct in S100B animals with the signal predominantly in the ganglion cell layer (GCL; detail image), the inner nuclear layer, and the outer segment. (C) A significant up-regulation of IMPG2 was observed in S100B animals 14 days after immunization $(p=0.031)$. (D) At 14 days, retinal cross-sections were labeled with an antibody against IMPG2 (red) and anti-GFAP (astrocytes; green), while DAPI stained cell nuclei (blue). In S100B retinae, IMPG2 signal was predominantly located in the GCL (detail image) and often co-localized with GFAP. (E) Analysis using mass spectrometry showed a significant up-regulation of PLS3 in S100B rats 7 days after immunization $(p=0.012)$. (F) At 7 days, retinae were labeled with antibodies against PLS3 (red) and GFAP (green). Cell nuclei were counterstained with DAPI (blue). PLS3 staining was more distinct in S100B animals. PLS3 ${ }^{+}$signal was localized in the GCL (detail image), inner nuclear layer, and outer segment. In the GCL, PLS3 was often co-localized with GFAP. GCL = ganglion cell layer; IPL = inner plexiform layer; INL = inner nuclear layer; $\mathrm{OPL}=$ outer plexiform layer; $\mathrm{ONL}=$ outer nuclear layer; $\mathrm{OS}=$ outer segment. Scale bars: $20 \mu \mathrm{m}$, scale bars detail: $10 \mu \mathrm{m} .{ }^{*} p<0.05$.

In addition, IMPG2 was found up-regulated in S100B rats compared to controls 14 days after immunization ( $p=0.031$; Figure 9C). Here, the distribution of the IMPG2 staining was not that evident in controls. In S00B retinae, IMPG2 staining was especially observed in the GCL, often co-localized with the astrocyte marker GFAP (Figure 9D).

At 7 days after S100B immunization, the actin-binding and bundling protein plastin 3 (PLS3) was found up-regulated ( $p=0.012$; Figure 9E). Immunohistological staining showed a weak distribution throughout the whole retina, with more intense signal in the outer segment in control rats. In S100B retinae, a stronger PLS3 staining, especially in the GCL and inner plexiform layers, could be revealed. In the GCL, the PLS3 staining was often co-localized with GFAP (Figure 9F).

\section{Discussion}

To identify key proteins which might play a role in the pathogenesis of glaucoma independent from elevated IOP, an established autoimmune glaucoma model was used for a proteomic analysis of retinae in this study. We previously demonstrated that an immunization with S100B leads to loss of RGCs and optic nerve degeneration after 28 days [27]. Nonetheless, (immunological) factors contributing to cell death are often found before a significant degeneration occurs. For example, a higher number of complement factors and more $\mathrm{NF}^{+} \mathrm{B}^{+}$cells were revealed 7 and/or 14 days after S100B immunization [40]. Hence, to determine possible early disease markers for glaucoma, we analyzed rat retinae 7 and 14 days after immunization. At these points in time, the number of RGCs was not altered between S100B and control animals, which is in accordance with previous findings [41]. This slow progression of cell loss mimics the damage course in glaucoma-like events [42].

We identified several altered proteins after S100B immunization in the current study. We chose to take a closer look at different proteins that are either already connected to glaucomatous neurodegeneration, e.g., HSP60, or that were of interest but were not previously linked to glaucoma, e.g., IMPG1.

In the brain, MAP-2 is the most abundant MAP. Microtubules are one of the major components of the neuronal cytoskeleton [43]. In our study, we found a down-regulation of two unique peptides of MAP-2 7 days after immunization. In the mammalian retina, MAP-2 expression is reported especially in RGCs, amacrine cells, and the inner segments of photoreceptors [44-46]. An up-regulation of MAP-2 is associated with stabilizing dendrites [47]. Hence, a down-regulation could hint towards a destabilization and could be a first sign of dendrite and cell loss. In R28 neuroretinal cells, an internalization of the amyloid beta peptide led to a transient disruption of MAP-2 [48]. In donor retinae of patients with age-related macular degeneration, MAP-2 labelling was noted in the inner segments of abnormal photoreceptors with abnormally located nuclei. Since not all abnormal neurons 
were MAP-2 positive, Pow and Sullivan assumed that MAP-2 expression might be transient and only occur during neuro-morphogenesis [49].

In the mammalian retina, amacrine cells are the largest cohort of neurons [50-52]. Amacrine cells are interneurons, which provide the integration of signals that are essential to the construction of the RGC visual message sent to the brain [53]. Further, they are highly diverse and use several neurotransmitters. Based on their ramification in the inner plexiform layer, amacrine cells can be classified into different subtypes. Those who use glycine are so-called small-field amacrine cells and the most common ones are class AII cells. Calretinin is localized in different neurons in the retinae of vertebrates [54]. Specifically, in the rat retina, direction-selective cholinergic cells contain calretinin [55]. The mass spectrometric analysis in our study showed an up-regulation of calretinin 14 days after S100B immunization. In contrast, the number of calretinin ${ }^{+}$cells in the inner nuclear layer counted after immunofluorescence staining remained unaltered. The discrepancy between those data can be explained by the different methods used. While, for immunohistology, only calretinin $^{+}$cells in the inner nuclear layer were counted, for mass spectrometry, the whole retina was processed and analyzed. Further, amacrine cells project presynaptic dendrites to the inner plexiform layer where they connect by synapses with RGCs [56]. Possibly, the increase of calretinin protein points towards early compensatory mechanisms, which were similarly described in Alzheimer's disease. Here, at first, the dysfunction of synapses and neurons triggers a compensatory response to maintain synaptic connectivity. Therefore, new synapses are formed and, in addition, the remaining ones increase their size [57-59].

We could previously show, that 14 days after S100B immunization, more GABA-A receptor $\alpha 3$ and NMDA receptor 1 synapses could be detected, this is before a significant cell loss occurred. In contrast, gephyrin, as a marker for inhibitory post-synapses, was not altered [35]. As our analyses showed, gephyrin is also not affected after 28 days. Gephyrin itself acts as an anchor protein by binding GABA-A receptors and glycine to the post-synaptic skeleton $[60,61]$. In the brain tissue of patients with Alzheimer's disease, an accumulation of gephyrin in co-localization with $\beta$-amyloid plaques was detected. Since gephyrin is involved in synaptic organization, the authors concluded that synaptic dysfunction is an early event in Alzheimer's disease [62]. In the EAG model, gephyrin itself could not be found to be altered at different points in time, suggesting a minor role in the pathogenesis. However, the precise function of synaptic alterations should be investigated further.

Over the last years, the contribution of HSPs to glaucomatous damage has been widely discussed [63]. HSPs can serve as antigen-presenters, but they can also be recognized as antigens, and they are, therefore, connected to the immune response [64,65]. With our mass spectrometric analyses, we could observe a down-regulation of two peptide sequences of HSP60 in retinae 14 days after immunization. Previously, a study by Wax et al. revealed elevated serum levels of HSP60 in NTG patients [66]. Further, post-mortem immunostaining in retinae and optic nerve heads in patients with and without elevated IOP showed a higher intensity of HSP60. HSP60 was observed predominantly in RGCs and photoreceptors [67]. In the aqueous humor of patients with primary open-angle glaucoma (POAG), elevated levels of HSP60 and HSP90 were found [68]. Guo et al. compared POAG and NTG patients and noted higher serum antibody titers only in NTG subjects [69]. In contrast, a case-control study conducted in Poland could not determine an increase of serum HSP60 levels in NTG and POAG patients compared to control subjects [70].

As mentioned in the introduction, the EAG model is based on the finding of autoantibodies in glaucoma patients. When applying HSP60 systemically in rats, a loss of RGCs, predominantly in the central part of the retina, was observed after 28 days [71]. Contrarily, in rats from our study, that were immunized with the glial protein S100B, a down-regulation of HSP60 was detected by mass spectrometry. Similar results were noted after an intravitreal S100B injection. Here, mass spectrometry data also revealed a down-regulation of HSP60 when comparing S100B to PBS-injected eyes [72]. It is possible that S100B itself is 
responsible for the observed down-regulation. For instance, S100B can bind to RAGE. In a diabetic mouse model, the advanced glycation end product (AGE)/RAGE axis causes mitochondrial dysfunction in pancreatic islet cells and a down-regulation of HSP60 [73]. It is known that HSP60 down-regulation can lead to morphological changes, deficient ATP syntheses, inhibitions in cell proliferation, and decreases in mitochondrial membrane potential $[74,75]$. The results of the different studies indicate that both too much and too little HSP60 could contribute to cell damage.

A further interesting protein we found up-regulated after S100B immunization is $\alpha 2$-macroglobulin, a plasma acute-phase protein. It can bind to various ligands including cytokines [76,77], growth factors [78-81], and misfolded proteins [82-85]. For instance, $\alpha 2$-macroglobulin can bind to pro-inflammatory mediators, such as tumor necrosis factor $\alpha(\mathrm{TNF} \alpha)$, interleukin (IL)-1 $\beta$, or IL-6 [86-88], leading to the assumption that it has an important role in controlling inflammatory mechanisms. Soluble $\alpha 2$-macroglobulin was noted in the aqueous humor of glaucoma patients as well as in a rat ocular hypertension (OHT) model [89]. Further, in OHT models (cauterization and saline injection), an upregulation of $\alpha 2$-macroglobulin in retinae could be detected. These changes were longlasting and continued even after pharmacological normalization of the IOP. In addition, the up-regulation occurred mainly in glia cells [90]. In our study, $\alpha 2$-macroglobulin was up-regulated in evaluations using mass spectrometry and immunohistology 7 and 14 days after S100B immunization. Hence, this protein might also play a role in RGC death, as proposed by Shi et al. [90]. In line with this, the neutralization of $\alpha 2$-macroglobulin in the vitreous and the inhibition of its function in the retina protected RGCs from glaucomatous damage [90-92].

Another acute-phase protein we found up-regulated after S100B immunization is serotransferrin. It is an iron-binding blood plasma protein that controls the levels of free iron in biological fluids [93]. Iron disbalance is known to increase oxidative stress and can, therefore, play a role in the pathogenesis of neurodegenerative diseases. For example, an increase of transferrin mRNA levels was observed in the temporal and frontal cortices of patients with Alzheimer's disease [94]. Studies also located a link between elevated serotransferrin levels and glaucoma. In a proteomic analyses of human donor retinae from glaucoma patients, the authors revealed an up-regulation of serotransferrin [95]. Further, in serum samples of POAG patients, a higher concentration of serotransferrin was measured [96]. Hence, in combination with the results of elevated $\alpha 2$-macroglobulin levels, acute-phase proteins appear to play a crucial role in the pathogenesis of glaucoma and should be explored in more detail in further studies.

Interestingly, mass spectrometry of the probes revealed a regulation of certain proteins after S100B immunization, which are not directly linked to glaucoma or RGCs, such as IMPG1 and IMPG2. IMPGs belong to the ECM, which is the non-cellular component of all organs and tissues. The ECM in the retina can be divided into two entities: the interphotoreceptor matrix surrounding the inner and outer segments of the photoreceptors and the retinal ECM that surrounds the other cells [97]. IMPG1 and IMPG2 are involved in the development and maintenance of photoreceptors [98-101]. In the current study, IMPG1 was up-regulated in retinae at 7 and IMPG2 at 14 days after S100B immunization. Previously, an enhanced immunostaining of the ECM proteins Tenascin- $C$ and phosphacan $/ \mathrm{RPTP} \beta / \zeta$ was identified in S100B optic nerves after 7 days [41]. Tenascin- $C$ showed enhanced immunoreactivity in the optic nerve after ischemia-reperfusion injury [102], while a knockout of Tenascin-C could protect the retinal function and rod-photoreceptor cells from ischemic damage [103].

Another protein found up-regulated 7 days after S100B immunization is myosin-10. It is an actin-based motor protein that participates in many essential intracellular processes, such as phagocytosis, cell migration, or filopodia formation [104]. In glaucomatous trabecular meshwork cells, myosin-10 distribution was disrupted [105]. In addition, myosin-10 might also play a role in focal ECM degradation in trabecular meshwork cells [106]. It is also known that myosin-10 binds to the NPxY motifs in the $\beta$-integrin cytoplasmic 
tail [107]. As a result of different integrin compositions, the ECM environment influences the regeneration and survival of adult RGC subtypes [108]. Hence, the remodeling of ECM proteins seems to contribute to retinal damage and a better understanding can provide new tools for diagnostic or therapeutic approaches in the future.

The observed results underline the multifactorial entity of the glaucoma disease. Immunological factors, especially, might serve as objective markers for diagnosis as well as disease progression in the future. Of course, these markers need to be further explored and validated in subsequent studies. Further, new therapeutic strategies could be developed based on the modulation and/or inhibition of immune system components. This could be used as adjuvant treatments in patients in addition to IOP-lowering drugs. However, new targets need to be explored first in (animal) models.

A limitation of our study is the fact that we performed proteomic analyses only at points in time where no RGC loss occurred. Although we specifically aimed to identify proteins early on in glaucoma, which might lead to cell death, it would also be interesting to perform those experiments at subsequent points in time after immunization. This would provide additional information about the changes of the retinal proteome in more chronic and advanced stages of glaucoma disease.

\section{Conclusions}

In our study, we identified 43 proteins which were significantly altered in S100B retinae after 7 days, and 67 altered proteins at 14 days. These shifts precede the loss of RGCs in S100B-immunized rats. Interestingly, serval regulated proteins were associated with the immune system, including beta-crystallin B1 and B3 or HSP60. Our observations provide comprehensive proteomic data to strengthen the pathophysiological impact of S100B and the involvement of the immune system in glaucoma. They can hopefully provide new hints towards disease markers or novel therapeutic approaches in the future.

Supplementary Materials: The following are available online at https:/ /www.mdpi.com/article/ 10.3390/biology11010016/s1, Table S1: Primary and secondary antibodies for immunohistology. Table S2: A total of 1287 proteins identified with at least one unique peptide in at least $80 \%$ of the control as well as the S100B samples at 7 days. Table S3: A total of 1384 proteins identified with least one unique peptide and $d$ in at least $80 \%$ of each study group at 14 days. Figure S1: Pathway analysis of rat retina-specific spectral library proteins. Figure S2: Pathway analysis of retinal proteins $7\left(A, B^{*}\right)$ and 14 days $\left(C, D^{*}\right)$ after S100B immunization. Figure S3: STRING protein-protein interaction network of significant proteins 7 days after S100B immunization. Figure S4: STRING protein-protein interaction network of significant proteins 14 days after S100B immunization.

Author Contributions: Conceptualization, S.C.J. and C.M.; formal analysis, S.R., A.G., J.T., L.B. and C.M.; methodology, S.R., A.G., J.T., L.B., P.G., S.K., B.S., H.B.D., K.M., S.C.J. and C.M.; investigation, S.R., A.G., J.T., L.B., P.G., S.K., B.S. and C.M.; resources, H.B.D., K.M., S.C.J. and C.M.; writingoriginal draft preparation, S.R., A.G., S.C.J. and C.M.; writing-review and editing, H.B.D., K.M., S.C.J. and C.M.; visualization, S.R., A.G., S.C.J. and C.M.; supervision, S.C.J. and C.M.; project administration, S.R., S.C.J. and C.M.; funding acquisition, S.R., S.C.J. and C.M. All authors have read and agreed to the published version of the manuscript.

Funding: This research was funded by Deutsche Forschungsgemeinschaft (DFG, grants JO-886/1-3 and RE-4543/1-1). Further support was provided by Deutsche Parkinson Gesellschaft, Research funding of the Faculty of Medicine at RUB (FoRUM), HUPO Brain Proteome Project (HBPP), Protein Unit for Research in Europe (PURE), a project of North Rhine-Westphalia, a federal German state, and by de.NBI, a project of the German Federal Ministry of Education and Research (FKZ 031 A 534A).

Institutional Review Board Statement: All experiments involving animals were approved by the animal care committee of North Rhine-Westphalia, Germany, and were performed in accordance with relevant guidelines and regulations (approval codes: 84-02-04.2013_A291 and 81-02-04.2018_A071).

Informed Consent Statement: Not applicable.

Data Availability Statement: Mass spectrometry data set of the study samples has been uploaded to ProteomeXchange with the identifier PXD023995. 
Conflicts of Interest: The authors declare no conflict of interest. The funders had no role in the design of the study, in the collection, analyses, or interpretation of the data; in the writing of the manuscript, or the decision to publish the results.

\section{References}

1. EGS. European Glaucoma Society Terminology and Guidelines for Glaucoma, 4th Edition-Chapter 2: Classification and terminology. Br. J. Ophthalmol. 2017, 101, 73-127. [CrossRef]

2. Hennis, A.; Wu, S.Y.; Nemesure, B.; Honkanen, R.; Leske, M.C.; Barbados Eye Studies, G. Awareness of incident open-angle glaucoma in a population study: The Barbados Eye Studies. Ophthalmology 2007, 114, 1816-1821. [CrossRef] [PubMed]

3. Leite, M.T.; Sakata, L.M.; Medeiros, F.A. Managing glaucoma in developing countries. Arq. Bras. Oftalmol. 2011, 74, 83-84. [CrossRef]

4. Rotchford, A.P.; Kirwan, J.F.; Muller, M.A.; Johnson, G.J.; Roux, P. Temba glaucoma study: A population-based cross-sectional survey in urban South Africa. Ophthalmology 2003, 110, 376-382. [CrossRef]

5. Sathyamangalam, R.V.; Paul, P.G.; George, R.; Baskaran, M.; Hemamalini, A.; Madan, R.V.; Augustian, J.; Prema, R.; Lingam, V. Determinants of glaucoma awareness and knowledge in urban Chennai. Indian J. Ophthalmol. 2009, 57, 355-360. [CrossRef] [PubMed]

6. Budenz, D.L.; Barton, K.; Whiteside-de Vos, J.; Schiffman, J.; Bandi, J.; Nolan, W.; Herndon, L.; Kim, H.; Hay-Smith, G.; Tielsch, J.M.; et al. Prevalence of glaucoma in an urban West African population: The Tema Eye Survey. JAMA Ophthalmol. 2013, 131, 651-658. [CrossRef]

7. Mallick, J.; Devi, L.; Malik, P.K.; Mallick, J. Update on Normal Tension Glaucoma. J. Ophthalmic Vis. Res. 2016, 11, 204-208. [CrossRef]

8. Sommer, A.; Tielsch, J.M.; Katz, J.; Quigley, H.A.; Gottsch, J.D.; Javitt, J.; Singh, K. Relationship between intraocular pressure and primary open angle glaucoma among white and black Americans. The Baltimore Eye Survey. Arch. Ophthalmol. 1991, 109, 1090-1095. [CrossRef]

9. Vasudevan, S.K.; Gupta, V.; Crowston, J.G. Neuroprotection in glaucoma. Indian J. Ophthalmol. 2011, 59 (Suppl. S1), S102-S113. [CrossRef]

10. Sucher, N.J.; Lipton, S.A.; Dreyer, E.B. Molecular basis of glutamate toxicity in retinal ganglion cells. Vis. Res. 1997, 37, 3483-3493. [CrossRef]

11. Tezel, G.; Wax, M.B. The immune system and glaucoma. Curr. Opin. Ophthalmol. 2004, 15, 80-84. [CrossRef] [PubMed]

12. Grus, F.H.; Joachim, S.C.; Wuenschig, D.; Rieck, J.; Pfeiffer, N. Autoimmunity and glaucoma. J. Glaucoma 2008, 17, 79-84. [CrossRef] [PubMed]

13. Wax, M.B. The case for autoimmunity in glaucoma. Exp. Eye Res. 2011, 93, 187-190. [CrossRef] [PubMed]

14. Joachim, S.C.; Pfeiffer, N.; Grus, F.H. Autoantibodies in patients with glaucoma: A comparison of IgG serum antibodies against retinal, optic nerve, and optic nerve head antigens. Graefes Arch. Clin. Exp. Ophthalmol. 2005, 243, 817-823. [CrossRef]

15. Joachim, S.C.; Bruns, K.; Lackner, K.J.; Pfeiffer, N.; Grus, F.H. Analysis of IgG antibody patterns against retinal antigens and antibodies to alpha-crystallin, GFAP, and alpha-enolase in sera of patients with "wet" age-related macular degeneration. Graefes Arch. Clin. Exp. Ophthalmol. 2007, 245, 619-626. [CrossRef] [PubMed]

16. Boehm, N.; Wolters, D.; Thiel, U.; Lossbrand, U.; Wiegel, N.; Pfeiffer, N.; Grus, F.H. New insights into autoantibody profiles from immune privileged sites in the eye: A glaucoma study. Brain Behav. Immun. 2012, 26, 96-102. [CrossRef]

17. Gramlich, O.W.; Beck, S.; von Thun Und Hohenstein-Blaul, N.; Boehm, N.; Ziegler, A.; Vetter, J.M.; Pfeiffer, N.; Grus, F.H. Enhanced insight into the autoimmune component of glaucoma: $\mathrm{IgG}$ autoantibody accumulation and pro-inflammatory conditions in human glaucomatous retina. PLoS ONE 2013, 8, e57557. [CrossRef]

18. Chang, E.E.; Goldberg, J.L. Glaucoma 2.0: Neuroprotection, neuroregeneration, neuroenhancement. Ophthalmology 2012, 119, 979-986. [CrossRef]

19. Pascale, A.; Drago, F.; Govoni, S. Protecting the retinal neurons from glaucoma: Lowering ocular pressure is not enough. Pharmacol. Res. 2012, 66, 19-32. [CrossRef]

20. Gupta, D.; Chen, P.P. Glaucoma. Am. Fam. Phys. 2016, 93, 668-674.

21. Grus, F.H.; Boehm, N.; Beck, S.; Schlich, M.; Lossbrandt, U.; Pfeiffer, N. Autoantibody Profiles in Tear Fluid as a Diagnostic Tool in Glaucoma. Investig. Ophthalmol. Vis. Sci. 2010, 51, 6110.

22. Michetti, F.; D'Ambrosi, N.; Toesca, A.; Puglisi, M.A.; Serrano, A.; Marchese, E.; Corvino, V.; Geloso, M.C. The S100B story: From biomarker to active factor in neural injury. J. Neurochem. 2019, 148, 168-187. [CrossRef] [PubMed]

23. Sorci, G.; Riuzzi, F.; Arcuri, C.; Tubaro, C.; Bianchi, R.; Giambanco, I.; Donato, R. S100B protein in tissue development, repair and regeneration. World J. Biol. Chem. 2013, 4, 1-12. [CrossRef] [PubMed]

24. Heizmann, C.W.; Fritz, G.; Schafer, B.W. S100 proteins: Structure, functions and pathology. Front. Biosci. A J. Virtual Libr. 2002, 7, d1356-d1368.

25. Bianchi, R.; Kastrisianaki, E.; Giambanco, I.; Donato, R. S100B protein stimulates microglia migration via RAGE-dependent up-regulation of chemokine expression and release. J. Biol. Chem. 2011, 286, 7214-7226. [CrossRef]

26. Langeh, U.; Singh, S. Targeting S100B Protein as a Surrogate Biomarker and its Role in Various Neurological Disorders. Curr. Neuropharmacol. 2021, 19, 265-277. [CrossRef] [PubMed] 
27. Noristani, R.; Kuehn, S.; Stute, G.; Reinehr, S.; Stellbogen, M.; Dick, H.B.; Joachim, S.C. Retinal and Optic Nerve Damage is Associated with Early Glial Responses in an Experimental Autoimmune Glaucoma Model. J. Mol. Neurosci. 2016, 58, 470-482. [CrossRef] [PubMed]

28. Casola, C.; Reinehr, S.; Kuehn, S.; Stute, G.; Spiess, B.M.; Dick, H.B.; Joachim, S.C. Specific Inner Retinal Layer Cell Damage in an Autoimmune Glaucoma Model Is Induced by GDNF With or Without HSP27. Investig. Ophthalmol. Vis. Sci. 2016, 57, 3626-3639. [CrossRef]

29. Casola, C.; Schiwek, J.E.; Reinehr, S.; Kuehn, S.; Grus, F.H.; Kramer, M.; Dick, H.B.; Joachim, S.C. S100 Alone Has the Same Destructive Effect on Retinal Ganglion Cells as in Combination with HSP 27 in an Autoimmune Glaucoma Model. J. Mol. Neurosci. 2015, 56, 228-236. [CrossRef] [PubMed]

30. Reinehr, S.; Guntermann, A.; Kuehn, S.; Palmhof, M.; Grotegut, P.; Serschnitzki, B.; Steinbach, S.; Dick, H.B.; Marcus, K.; Joachim, S.C.; et al. Rat retinae data for use as spectral library, for pathway remodeling as well as protein mapping. Data Brief 2021, 37, 107212. [CrossRef]

31. Steinbach, S.; Serschnitzki, B.; Gerlach, M.; Marcus, K.; May, C. Spiked human. Data Brief 2019, 23, 103711. [CrossRef] [PubMed]

32. Barkovits, K.; Pacharra, S.; Pfeiffer, K.; Steinbach, S.; Eisenacher, M.; Marcus, K.; Uszkoreit, J. Reproducibility, Specificity and Accuracy of Relative Quantification Using Spectral Library-based Data-independent Acquisition. Mol. Cell. Proteom. 2020, 19, 181-197. [CrossRef] [PubMed]

33. Jassal, B.; Matthews, L.; Viteri, G.; Gong, C.; Lorente, P.; Fabregat, A.; Sidiropoulos, K.; Cook, J.; Gillespie, M.; Haw, R.; et al. The reactome pathway knowledgebase. Nucleic Acids Res. 2020, 48, D498-D503. [CrossRef]

34. Szklarczyk, D.; Gable, A.L.; Nastou, K.C.; Lyon, D.; Kirsch, R.; Pyysalo, S.; Doncheva, N.T.; Legeay, M.; Fang, T.; Bork, P.; et al. The STRING database in 2021: Customizable protein-protein networks, and functional characterization of user-uploaded gene/measurement sets. Nucleic Acids Res. 2021, 49, D605-D612. [CrossRef]

35. Benning, L.; Reinehr, S.; Grotegut, P.; Kuehn, S.; Stute, G.; Dick, H.B.; Joachim, S.C. Synapse and Receptor Alterations in Two Different S100B-Induced Glaucoma-Like Models. Int. J. Mol. Sci. 2020, 21, 6998. [CrossRef] [PubMed]

36. Reinehr, S.; Kuehn, S.; Casola, C.; Koch, D.; Stute, G.; Grotegut, P.; Dick, H.B.; Joachim, S.C. HSP27 immunization reinforces AII amacrine cell and synapse damage induced by S100 in an autoimmune glaucoma model. Cell Tissue Res. 2018, 371, 237-249. [CrossRef]

37. Casson, R.J.; Chidlow, G.; Crowston, J.G.; Williams, P.A.; Wood, J.P.M. Retinal energy metabolism in health and glaucoma. Prog. Retin. Eye Res. 2021, 81, 100881. [CrossRef] [PubMed]

38. Doozandeh, A.; Yazdani, S. Neuroprotection in Glaucoma. J. Ophthalmic Vis. Res. 2016, 11, 209-220. [CrossRef]

39. Christensen, I.; Lu, B.; Yang, N.; Huang, K.; Wang, P.; Tian, N. The Susceptibility of Retinal Ganglion Cells to Glutamatergic Excitotoxicity Is Type-Specific. Front. Neurosci. 2019, 13, 219. [CrossRef] [PubMed]

40. Reinehr, S.; Reinhard, J.; Gandej, M.; Gottschalk, I.; Stute, G.; Faissner, A.; Dick, H.B.; Joachim, S.C. S100B immunization triggers NFKB and complement activation in an autoimmune glaucoma model. Sci. Rep. 2018, 8, 9821. [CrossRef] [PubMed]

41. Reinehr, S.; Reinhard, J.; Wiemann, S.; Stute, G.; Kuehn, S.; Woestmann, J.; Dick, H.B.; Faissner, A.; Joachim, S.C. Early remodelling of the extracellular matrix proteins tenascin-C and phosphacan in retina and optic nerve of an experimental autoimmune glaucoma model. J. Cell. Mol. Med. 2016, 20, 2122-2137. [CrossRef] [PubMed]

42. Quigley, H.A. Open-angle glaucoma. N. Engl. J. Med. 1993, 328, 1097-1106. [CrossRef] [PubMed]

43. Johnson, G.V.; Jope, R.S. The role of microtubule-associated protein 2 (MAP-2) in neuronal growth, plasticity, and degeneration. J. Neurosci. Res. 1992, 33, 505-512. [CrossRef] [PubMed]

44. Okabe, S.; Shiomura, Y.; Hirokawa, N. Immunocytochemical localization of microtubule-associated proteins $1 \mathrm{~A}$ and 2 in the rat retina. Brain Res. 1989, 483, 335-346. [CrossRef]

45. Gabriel, R.; Wilhelm, M.; Straznicky, C. Microtubule-associated protein 2 (MAP2)-immunoreactive neurons in the retina of Bufo marinus: Colocalisation with tyrosine hydroxylase and serotonin in amacrine cells. Cell Tissue Res. 1992, 269, 175-182. [CrossRef]

46. Tucker, R.P.; Matus, A.I. Microtubule-associated proteins characteristic of embryonic brain are found in the adult mammalian retina. Dev. Biol. 1988, 130, 423-434. [CrossRef]

47. Vaillant, A.R.; Zanassi, P.; Walsh, G.S.; Aumont, A.; Alonso, A.; Miller, F.D. Signaling mechanisms underlying reversible, activity-dependent dendrite formation. Neuron 2002, 34, 985-998. [CrossRef]

48. Taylor-Walker, G.; Lynn, S.A.; Keeling, E.; Munday, R.; Johnston, D.A.; Page, A.; Scott, J.A.; Goverdhan, S.; Lotery, A.J.; Ratnayaka, J.A. The Alzheimer's-related amyloid beta peptide is internalised by R28 neuroretinal cells and disrupts the microtubule associated protein 2 (MAP-2). Exp. Eye Res. 2016, 153, 110-121. [CrossRef]

49. Pow, D.V.; Sullivan, R.K. Nuclear kinesis, neurite sprouting and abnormal axonal projections of cone photoreceptors in the aged and AMD-afflicted human retina. Exp. Eye Res. 2007, 84, 850-857. [CrossRef] [PubMed]

50. Kolb, H. Amacrine cells of the mammalian retina: Neurocircuitry and functional roles. Eye 1997, 11 Pt 6, 904-923. [CrossRef] [PubMed]

51. Masland, R.H. The neuronal organization of the retina. Neuron 2012, 76, 266-280. [CrossRef]

52. Wassle, H.; Boycott, B.B. Functional architecture of the mammalian retina. Physiol. Rev. 1991, 71, 447-480. [CrossRef]

53. Akopian, A.; Kumar, S.; Ramakrishnan, H.; Viswanathan, S.; Bloomfield, S.A. Amacrine cells coupled to ganglion cells via gap junctions are highly vulnerable in glaucomatous mouse retinas. J. Comp. Neurol. 2016, 527, 159-173. [CrossRef] 
54. Pasteels, B.; Rogers, J.; Blachier, F.; Pochet, R. Calbindin and calretinin localization in retina from different species. Vis. Neurosci. 1990, 5, 1-16. [CrossRef]

55. Gabriel, R.; Witkovsky, P. Cholinergic, but not the rod pathway-related glycinergic (All), amacrine cells contain calretinin in the rat retina. Neurosci. Lett. 1998, 247, 179-182. [CrossRef]

56. Balasubramanian, R.; Gan, L. Development of Retinal Amacrine Cells and Their Dendritic Stratification. Curr. Ophthalmol. Rep. 2014, 2, 100-106. [CrossRef] [PubMed]

57. Boncristiano, S.; Calhoun, M.E.; Howard, V.; Bondolfi, L.; Kaeser, S.A.; Wiederhold, K.H.; Staufenbiel, M.; Jucker, M. Neocortical synaptic bouton number is maintained despite robust amyloid deposition in APP23 transgenic mice. Neurobiol. Aging 2005, 26, 607-613. [CrossRef] [PubMed]

58. Jansen, D.; Janssen, C.I.; Vanmierlo, T.; Dederen, P.J.; van Rooij, D.; Zinnhardt, B.; Nobelen, C.L.; Janssen, A.L.; Hafkemeijer, A.; Mutsaers, M.P.; et al. Cholesterol and synaptic compensatory mechanisms in Alzheimer's disease mice brain during aging. J. Alzheimer's Dis. JAD 2012, 31, 813-826. [CrossRef]

59. Scheff, S.W.; Price, D.A. Synaptic pathology in Alzheimer's disease: A review of ultrastructural studies. Neurobiol. Aging 2003, 24, 1029-1046. [CrossRef]

60. Choii, G.; Ko, J. Gephyrin: A central GABAergic synapse organizer. Exp. Mol. Med. 2015, 47, e158. [CrossRef] [PubMed]

61. Tyagarajan, S.K.; Fritschy, J.M. Gephyrin: A master regulator of neuronal function? Nat. Rev. Neurosci. 2014, 15, 141-156. [CrossRef]

62. Hales, C.M.; Rees, H.; Seyfried, N.T.; Dammer, E.B.; Duong, D.M.; Gearing, M.; Montine, T.J.; Troncoso, J.C.; Thambisetty, M.; Levey, A.I.; et al. Abnormal gephyrin immunoreactivity associated with Alzheimer disease pathologic changes. J. Neuropathol. Exp. Neurol. 2013, 72, 1009-1015. [CrossRef]

63. Tsai, T.; Grotegut, P.; Reinehr, S.; Joachim, S.C. Role of Heat Shock Proteins in Glaucoma. Int. J. Mol. Sci. 2019, 20, 5160. [CrossRef] [PubMed]

64. Binder, R.J. Functions of heat shock proteins in pathways of the innate and adaptive immune system. J. Immunol. 2014, 193, 5765-5771. [CrossRef] [PubMed]

65. Srivastava, P. Roles of heat-shock proteins in innate and adaptive immunity. Nat. Rev. Immunol. 2002, 2, 185-194. [CrossRef] [PubMed]

66. Wax, M.B.; Tezel, G.; Saito, I.; Gupta, R.S.; Harley, J.B.; Li, Z.; Romano, C. Anti-Ro/SS-A positivity and heat shock protein antibodies in patients with normal-pressure glaucoma. Am. J. Ophthalmol. 1998, 125, 145-157. [CrossRef]

67. Tezel, G.; Hernandez, R.; Wax, M.B. Immunostaining of heat shock proteins in the retina and optic nerve head of normal and glaucomatous eyes. Arch. Ophthalmol. 2000, 118, 511-518. [CrossRef] [PubMed]

68. Saccà, S.C.; Centofanti, M.; Izzotti, A. New Proteins as Vascular Biomarkers in Primary Open Angle Glaucomatous Aqueous Humor. Investig. Ophthalmol. Vis. Sci. 2012, 53, 4242-4253. [CrossRef]

69. Guo, C.; Wu, N.; Niu, X.; Wu, Y.; Chen, D.; Guo, W. Comparison of T Helper Cell Patterns in Primary Open-Angle Glaucoma and Normal-Pressure Glaucoma. Med. Sci. Monit. Int. Med. J. Exp. Clin. Res. 2018, 24, 1988-1996. [CrossRef] [PubMed]

70. Grabska-Liberek, I.; Skonieczna, K.; Olesinska, M.; Terelak-Borys, B.; Kociecki, J.; Sikora, M.; Jamrozy-Witkowska, A.; Tesla, P.; Czarnocka, B. Levels of antibodies against human heat shock protein (HSP) 60 in patients with glaucoma in Poland. Med. Sci. Monit. Int. Med. J. Exp. Clin. Res. 2015, 21, 828-832. [CrossRef]

71. Wax, M.B.; Tezel, G.; Yang, J.; Peng, G.; Patil, R.V.; Agarwal, N.; Sappington, R.M.; Calkins, D.J. Induced autoimmunity to heat shock proteins elicits glaucomatous loss of retinal ganglion cell neurons via activated T-cell-derived fas-ligand. $J$. Neurosci. 2008, 28, 12085-12096. [CrossRef]

72. Grotegut, P.; Perumal, N.; Kuehn, S.; Smit, A.; Dick, H.B.; Grus, F.H.; Joachim, S.C. Minocycline reduces inflammatory response and cell death in a S100B retina degeneration model. I. Neuroinflamm. 2020, 17, 375. [CrossRef] [PubMed]

73. Guan, S.S.; Sheu, M.L.; Yang, R.S.; Chan, D.C.; Wu, C.T.; Yang, T.H.; Chiang, C.K.; Liu, S.H. The pathological role of advanced glycation end products-downregulated heat shock protein 60 in islet beta-cell hypertrophy and dysfunction. Oncotarget 2016, 7 , 23072-23087. [CrossRef] [PubMed]

74. Bie, A.S.; Palmfeldt, J.; Hansen, J.; Christensen, R.; Gregersen, N.; Corydon, T.J.; Bross, P. A cell model to study different degrees of Hsp60 deficiency in HEK293 cells. Cell Stress Chaperones 2011, 16, 633-640. [CrossRef]

75. Magnoni, R.; Palmfeldt, J.; Christensen, J.H.; Sand, M.; Maltecca, F.; Corydon, T.J.; West, M.; Casari, G.; Bross, P. Late onset motoneuron disorder caused by mitochondrial Hsp60 chaperone deficiency in mice. Neurobiol. Dis. 2013, 54, 12-23. [CrossRef] [PubMed]

76. Gonias, S.L.; Carmichael, A.; Mettenburg, J.M.; Roadcap, D.W.; Irvin, W.P.; Webb, D.J. Identical or overlapping sequences in the primary structure of human alpha(2)-macroglobulin are responsible for the binding of nerve growth factor-beta, platelet-derived growth factor-BB, and transforming growth factor-beta. J. Biol. Chem. 2000, 275, 5826-5831. [CrossRef] [PubMed]

77. LaMarre, J.; Wollenberg, G.K.; Gonias, S.L.; Hayes, M.A. Cytokine binding and clearance properties of proteinase-activated alpha 2-macroglobulins. Lab. Investig. A J. Tech. Methods Pathol. 1991, 65, 3-14.

78. Barcelona, P.F.; Saragovi, H.U. A Pro-Nerve Growth Factor (proNGF) and NGF Binding Protein, alpha2-Macroglobulin, Differentially Regulates p75 and TrkA Receptors and Is Relevant to Neurodegeneration Ex Vivo and In Vivo. Mol. Cell. Biol. 2015, 35, 3396-3408. [CrossRef] [PubMed] 
79. Skornicka, E.L.; Shi, X.; Koo, P.H. Comparative binding of biotinylated neurotrophins to alpha(2)-macroglobulin family of proteins: Relationship between cytokine-binding and neuro-modulatory activities of the macroglobulins. J. Neurosci. Res. 2002, 67, 346-353. [CrossRef]

80. Westwood, M.; Aplin, J.D.; Collinge, I.A.; Gill, A.; White, A.; Gibson, J.M. alpha 2-Macroglobulin: A new component in the insulin-like growth factor/insulin-like growth factor binding protein-1 axis. J. Biol. Chem. 2001, 276, 41668-41674. [CrossRef]

81. Wolf, B.B.; Gonias, S.L. Neurotrophin binding to human alpha 2-macroglobulin under apparent equilibrium conditions. Biochemistry 1994, 33, 11270-11277. [CrossRef]

82. French, K.; Yerbury, J.J.; Wilson, M.R. Protease activation of alpha2-macroglobulin modulates a chaperone-like action with broad specificity. Biochemistry 2008, 47, 1176-1185. [CrossRef] [PubMed]

83. Whiten, D.R.; Cox, D.; Horrocks, M.H.; Taylor, C.G.; De, S.; Flagmeier, P.; Tosatto, L.; Kumita, J.R.; Ecroyd, H.; Dobson, C.M.; et al. Single-Molecule Characterization of the Interactions between Extracellular Chaperones and Toxic alpha-Synuclein Oligomers. Cell Rep. 2018, 23, 3492-3500. [CrossRef]

84. Wyatt, A.R.; Zammit, N.W.; Wilson, M.R. Acute phase proteins are major clients for the chaperone action of alpha(2)-macroglobulin in human plasma. Cell Stress Chaperones 2013, 18, 161-170. [CrossRef]

85. Yerbury, J.J.; Kumita, J.R.; Meehan, S.; Dobson, C.M.; Wilson, M.R. alpha2-Macroglobulin and haptoglobin suppress amyloid formation by interacting with prefibrillar protein species. J. Biol. Chem. 2009, 284, 4246-4254. [CrossRef]

86. Wollenberg, G.K.; LaMarre, J.; Rosendal, S.; Gonias, S.L.; Hayes, M.A. Binding of tumor necrosis factor alpha to activated forms of human plasma alpha 2 macroglobulin. Am. J. Pathol. 1991, 138, 265-272.

87. Borth, W.; Urbanski, A.; Prohaska, R.; Susanj, M.; Luger, T.A. Binding of recombinant interleukin-1 beta to the third complement component and alpha 2-macroglobulin after activation of serum by immune complexes. Blood 1990, 75, 2388-2395. [CrossRef]

88. Matsuda, T.; Hirano, T.; Nagasawa, S.; Kishimoto, T. Identification of alpha 2-macroglobulin as a carrier protein for IL-6. J. Immunol. 1989, 142, 148-152.

89. Bai, Y.; Sivori, D.; Woo, S.B.; Neet, K.E.; Lerner, S.F.; Saragovi, H.U. During glaucoma, alpha2-macroglobulin accumulates in aqueous humor and binds to nerve growth factor, neutralizing neuroprotection. Investig. Opthalmol. Vis. Sci. 2011, 52, 5260-5265. [CrossRef] [PubMed]

90. Shi, Z.; Rudzinski, M.; Meerovitch, K.; Lebrun-Julien, F.; Birman, E.; Di Polo, A.; Saragovi, H.U. Alpha2-macroglobulin is a mediator of retinal ganglion cell death in glaucoma. J. Biol. Chem. 2008, 283, 29156-29165. [CrossRef] [PubMed]

91. Bai, Y.; Shi, Z.; Zhuo, Y.; Liu, J.; Malakhov, A.; Ko, E.; Burgess, K.; Schaefer, H.; Esteban, P.F.; Tessarollo, L.; et al. In glaucoma the upregulated truncated TrkC.T1 receptor isoform in glia causes increased TNF-alpha production, leading to retinal ganglion cell death. Investig. Opthalmology Vis. Sci. 2010, 51, 6639-6651. [CrossRef] [PubMed]

92. Bai, Y.; Dergham, P.; Nedev, H.; Xu, J.; Galan, A.; Rivera, J.C.; ZhiHua, S.; Mehta, H.M.; Woo, S.B.; Sarunic, M.V.; et al. Chronic and acute models of retinal neurodegeneration TrkA activity are neuroprotective whereas p75NTR activity is neurotoxic through a paracrine mechanism. J. Biol. Chem. 2010, 285, 39392-39400. [CrossRef] [PubMed]

93. Cornelissen, A.; Guo, L.; Sakamoto, A.; Virmani, R.; Finn, A.V. New insights into the role of iron in inflammation and atherosclerosis. EBioMedicine 2019, 47, 598-606. [CrossRef]

94. Castillo, E.; Leon, J.; Mazzei, G.; Abolhassani, N.; Haruyama, N.; Saito, T.; Saido, T.; Hokama, M.; Iwaki, T.; Ohara, T.; et al. Author Correction: Comparative profiling of cortical gene expression in Alzheimer's disease patients and mouse models demonstrates a link between amyloidosis and neuroinflammation. Sci. Rep. 2021, 11, 18377. [CrossRef]

95. Funke, S.; Perumal, N.; Beck, S.; Gabel-Scheurich, S.; Schmelter, C.; Teister, J.; Gerbig, C.; Gramlich, O.W.; Pfeiffer, N.; Grus, F.H. Glaucoma related Proteomic Alterations in Human Retina Samples. Sci. Rep. 2016, 6, 29759. [CrossRef]

96. Gonzalez-Iglesias, H.; Alvarez, L.; Garcia, M.; Escribano, J.; Rodriguez-Calvo, P.P.; Fernandez-Vega, L.; Coca-Prados, M. Comparative proteomic study in serum of patients with primary open-angle glaucoma and pseudoexfoliation glaucoma. $J$. Proteom. 2014, 98, 65-78. [CrossRef]

97. Ishikawa, M.; Sawada, Y.; Yoshitomi, T. Structure and function of the interphotoreceptor matrix surrounding retinal photoreceptor cells. Exp. Eye Res. 2015, 133, 3-18. [CrossRef]

98. Felemban, M.; Dorgau, B.; Hunt, N.C.; Hallam, D.; Zerti, D.; Bauer, R.; Ding, Y.; Collin, J.; Steel, D.; Krasnogor, N.; et al. Extracellular matrix component expression in human pluripotent stem cell-derived retinal organoids recapitulates retinogenesis in vivo and reveals an important role for IMPG1 and CD44 in the development of photoreceptors and interphotoreceptor matrix. Acta Biomater. 2018, 74, 207-221. [CrossRef]

99. Kuehn, M.H.; Hageman, G.S. Expression and characterization of the IPM 150 gene (IMPG1) product, a novel human photoreceptor cell-associated chondroitin-sulfate proteoglycan. Matrix Biol. J. Int. Soc. Matrix Biol. 1999, 18, 509-518. [CrossRef]

100. Acharya, S.; Rodriguez, I.R.; Moreira, E.F.; Midura, R.J.; Misono, K.; Todres, E.; Hollyfield, J.G. SPACR, a novel interphotoreceptor matrix glycoprotein in human retina that interacts with hyaluronan. J. Biol. Chem. 1998, 273, 31599-31606. [CrossRef]

101. Chen, Q.; Lee, J.W.; Nishiyama, K.; Shadrach, K.G.; Rayborn, M.E.; Hollyfield, J.G. SPACRCAN in the interphotoreceptor matrix of the mouse retina: Molecular, developmental and promoter analysis. Exp. Eye Res. 2003, 76, 1-14. [CrossRef]

102. Reinhard, J.; Renner, M.; Wiemann, S.; Shakoor, D.A.; Stute, G.; Dick, H.B.; Faissner, A.; Joachim, S.C. Ischemic injury leads to extracellular matrix alterations in retina and optic nerve. Sci. Rep. 2017, 7, 43470. [CrossRef] 
103. Wiemann, S.; Yousf, A.; Joachim, S.C.; Peters, C.; Mueller-Buehl, A.M.; Wagner, N.; Reinhard, J. Knock-Out of Tenascin-C Ameliorates Ischemia-Induced Rod-Photoreceptor Degeneration and Retinal Dysfunction. Front. Neurosci. 2021, 15, 642176. [CrossRef] [PubMed]

104. Takagi, Y.; Farrow, R.E.; Billington, N.; Nagy, A.; Batters, C.; Yang, Y.; Sellers, J.R.; Molloy, J.E. Myosin-10 produces its power-stroke in two phases and moves processively along a single actin filament under low load. Proc. Natl. Acad. Sci. USA 2014, 111, E1833-E1842. [CrossRef] [PubMed]

105. Sun, Y.Y.; Bradley, J.M.; Keller, K.E. Phenotypic and Functional Alterations in Tunneling Nanotubes Formed by Glaucomatous Trabecular Meshwork Cells. Investig. Opthalmol. Vis. Sci. 2019, 60, 4583-4595. [CrossRef]

106. Sun, Y.Y.; Yang, Y.F.; Keller, K.E. Myosin-X Silencing in the Trabecular Meshwork Suggests a Role for Tunneling Nanotubes in Outflow Regulation. Investig. Opthalmol. Vis. Sci. 2019, 60, 843-851. [CrossRef] [PubMed]

107. Zhang, P.; Azizi, L.; Kukkurainen, S.; Gao, T.; Baikoghli, M.; Jacquier, M.-C.; Sun, Y.; Määttä, J.A.E.; Cheng, R.H.; Wehrle-Haller, B.; et al. Crystal structure of the FERM-folded talin head reveals the determinants for integrin binding. Proc. Natl. Acad. Sci. USA 2020, 117, 32402-32412. [CrossRef] [PubMed]

108. Vecino, E.; Heller, J.P.; Veiga-Crespo, P.; Martin, K.R.; Fawcett, J.W. Influence of extracellular matrix components on the expression of integrins and regeneration of adult retinal ganglion cells. PLoS ONE 2015, 10, e0125250. [CrossRef] 